Article

\title{
Constraints from Geochemistry and Field Relationships for the Origin of Kornerupine-Bearing Gneiss from the Grenvillian New Jersey Highlands and Implications for the Source of Boron
}

\author{
Richard A. Volkert ${ }^{\dagger}$ \\ New Jersey Geological and Water Survey, 29 Arctic Parkway, Trenton, NJ 08625, USA; rvolkert@comcast.net \\ + The author is retired.
}

Received: 11 June 2019; Accepted: 12 July 2019; Published: 14 July 2019

\begin{abstract}
Kornerupine \pm prismatine is present in granulite-facies paragneiss at two locations in the Grenvillian New Jersey Highlands, occurring in an assemblage composed of quartz + biotite $+\mathrm{K}$-feldspar + plagioclase + garnet $+\mathrm{Fe}$-Ti oxides \pm sillimanite \pm rutile \pm graphite. Estimates of the metamorphic conditions of the host gneiss are $\geq 600 \mathrm{MPa}$ and $\sim 740{ }^{\circ} \mathrm{C}$ during the Ottawan phase of the Grenvillian Orogeny. Geochemical compositions of kornerupine-bearing gneiss are consistent with protoliths that were graywacke sandstone and pelite. Metagraywacke is characterized by (in wt. \%) $62-76 \% \mathrm{SiO}_{2}, 0.3-0.8 \% \mathrm{TiO}_{2}, 13-16 \% \mathrm{Al}_{2} \mathrm{O}_{3}, 0.6-4.3 \% \mathrm{CaO}, 2.2-6.4 \% \mathrm{Na}_{2} \mathrm{O}, 1.7-7.4 \%$ $\mathrm{K}_{2} \mathrm{O}$, and 90-260 ppm Zr; metapelite has lower $\mathrm{SiO}_{2}$ (53-66\%) and $\mathrm{CaO}(0.5-2.0 \%)$, higher $\mathrm{TiO}_{2}$ $(0.9-1.8 \%), \mathrm{Al}_{2} \mathrm{O}_{3},(15-26 \%)$, and $\mathrm{Zr}(210-490 \mathrm{ppm})$, and comparable $\mathrm{Na}_{2} \mathrm{O}(2.5-4.9 \%)$ and $\mathrm{K}_{2} \mathrm{O}$ (2.5-7.4\%). Indices of weathering and alteration yield low to intermediate values implying a relatively unweathered sediment source. Provenance discriminants suggest the protoliths formed from immature, first-cycle sediments derived mainly from a felsic arc-related source. The geological relationships of kornerupine-bearing gneiss are most compatible with boron sourced from B-rich sediments deposited in the protoliths between ca. 1299 and 1238 Ma. The breakdown of these sediments due to dehydration reactions during Ottawan prograde metamorphism led to mobilization of a B-rich fluid that migrated short distances to favorable structural sites in the host gneiss, resulting in precipitation of the borosilicates.
\end{abstract}

Keywords: Grenvillian Orogeny; New Jersey Highlands; supracrustal paragneiss; kornerupine; boron

\section{Introduction}

Kornerupine is a complex hydrous magnesium-iron-aluminum borosilicate that has an orthorhombic crystal structure and a boron content of $<0.5$ atoms per formula unit [1]. In addition to its use as a specific mineral name, kornerupine is also a group name for borosilicate minerals such as prismatine and grandidierite that have a kornerupine-like crystal structure and boron of $>0.5$ atoms per formula unit [1]. Although not a common mineral, kornerupine is found at numerous locations worldwide in diverse Proterozoic $\mathrm{Mg}$ - and Al-rich rock types metamorphosed at conditions of amphibolite to granulite facies. Of particular relevance to this study are those occurrences hosted by aluminous paragneiss that have been reported from locations such as Canada [2], India [3], Australia [4], Madagascar [5], and Antarctica [6]. Kornerupine-bearing paragneiss from each of these locations contains some variation of the mineral assemblage kornerupine + biotite + quartz + K-feldspar + garnet + cordierite + magnetite/ilmenite \pm plagioclase \pm grandidierite. Metamorphic conditions of the host gneiss at these locations overlap, with estimates of pressure $(P)$ ranging from $500-750 \mathrm{MPa}$ 
and temperature $(T)$ ranging from $650-760^{\circ} \mathrm{C}$, indicative of peak conditions of upper amphibolite to granulite facies.

In the New Jersey Highlands, kornerupine is recognized at two locations, both of which are hosted by Mesoproterozoic granulite-facies paragneiss. The first find of kornerupine was in 1969 at Mase Mountain (Figure 1) by Davis Young during field work for his $\mathrm{PhD}$, and details of that occurrence were eventually published [7]. The second find was in 2008 at Ringwood (Figure 1) during geologic mapping by the author. Preliminary field identification of the crystals there as tourmaline was subsequently refined through $\mathrm{X}$-ray diffraction analysis, permitting a more precise identification of kornerupine. Thus far nothing has been published with respect to the Ringwood location.

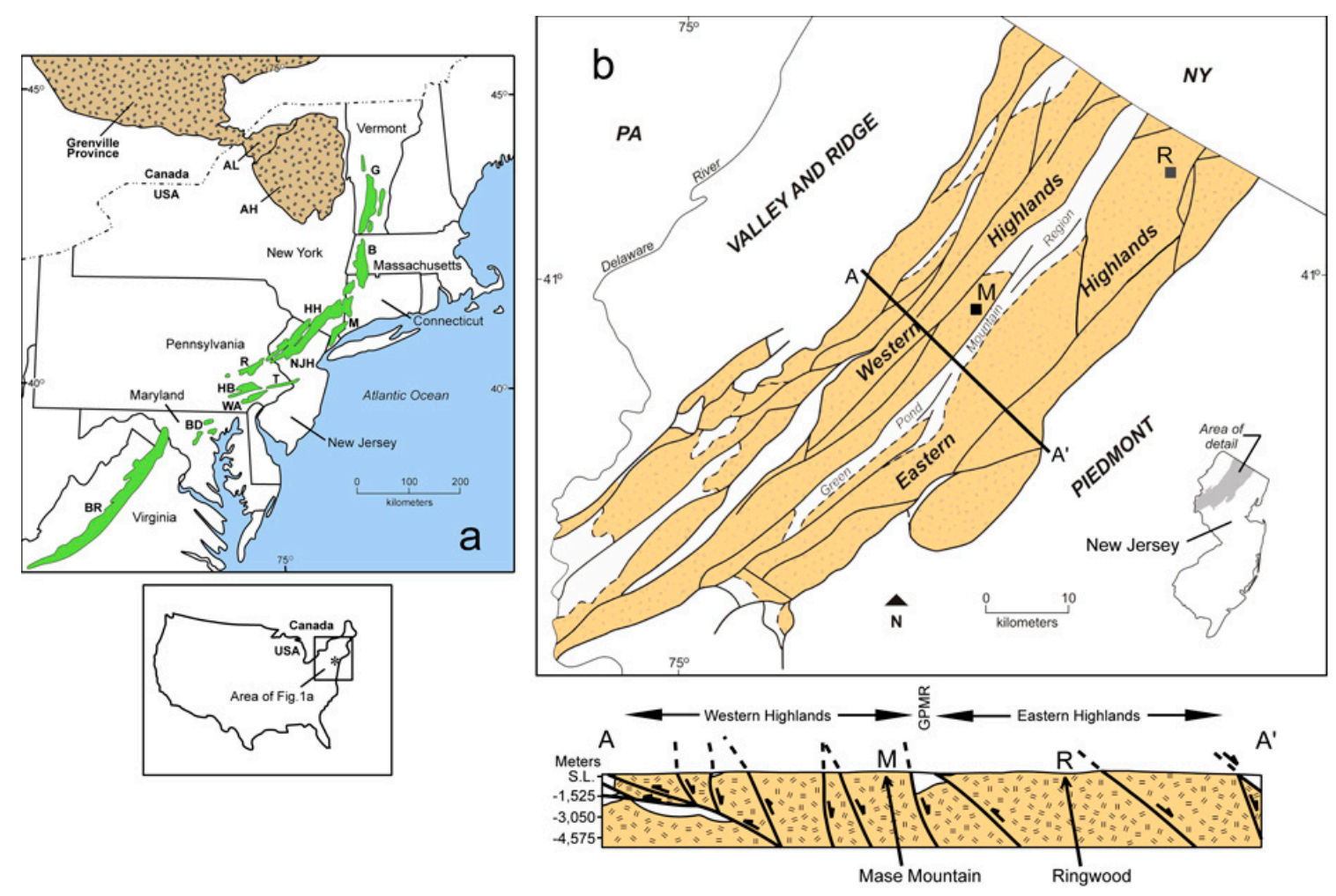

Figure 1. (a) Distribution of Grenville-age rocks in central and northern Appalachian inliers (green), the Adirondack Highlands (AH), Lowlands (AL), and the Grenville Province of southeastern Canada (brown). Abbreviations: Vermont Green Mountains (G); Massachusetts Berkshire Mountains (B); New York Hudson Highlands (HH); New Jersey Highlands (H); Trenton Prong (T); Pennsylvania Reading Prong (R); Honey Brook Upland (HB); West Chester and Avondale Massifs (WA); Maryland Baltimore Gneiss domes (BD); and Virginia Blue Ridge (BR). Small map locates area of Grenville rocks in the eastern United States and Canada listed above; asterisk locates New Jersey. (b) Simplified geologic map of the Grenvillian New Jersey Highlands (light brown) [8]. Squares locate kornerupine locations at Ringwood (R) and Mase Mountain (M). Kornerupine locations are projected onto line of cross section A-A' for comparison.

This paper provides the first descriptive information of the geological relationships of kornerupine from Ringwood, and a detailed synthesis of the geological relationships at the two locations, based on field observations, bulk rock mineralogy, and geochemistry. The results of this study provide reasonable constraints for the provenance and depositional environment of the protoliths of the host gneiss, as well as for possible sources of boron and the timing and environment of formation of borosilicates in the protoliths. 


\section{Geologic Setting}

The New Jersey Highlands constitute one of numerous inliers of Grenvillian rocks that extend along eastern North America south of the Grenville Province in Canada (Figure 1). Rocks of Mesoproterozoic age underlie most of the Highlands that is separated into western and eastern parts by downfaulted Middle to Lower Paleozoic rocks of the Green Pond Mountain Region. Along their southeastern border, the Mesoproterozoic rocks are in fault contact with Mesozoic sedimentary and igneous rocks of the Piedmont, and along their northwestern border, and within fault-bounded valleys, they are unconformably overlain by, or in fault contact with, Lower Paleozoic clastic and carbonate cover rocks of the Valley and Ridge (Figure 1).

Mesoproterozoic rocks of the Highlands include a heterogeneous assemblage of lithotectonic units that record a complex evolution. The calc-alkaline Wanaque tonalite gneiss ( $\mathrm{U}-\mathrm{Pb}$ zircon ages of $1366 \pm 9$ to $1363 \pm 17 \mathrm{Ma}$ ) and gneissic rhyolite, dacite, tonalite, diorite, and amphibolite of the Losee Suite (U-Pb zircon ages of $1282 \pm 7$ to $1248 \pm 12 \mathrm{Ma}$ ) are interpreted as having formed in a continental magmatic arc above a west-dipping subduction zone outboard of the eastern Laurentian margin [9]. These plutonic arc rocks are spatially associated with a thick sequence of supracrustal rocks that include bimodal felsic and mafic metavolcanic rocks, quartzofeldspathic and calc-silicate paragneiss, and marble that were formed in a back-arc basin inboard of the magmatic arc [10]. Of these, felsic metavolcanic rocks from different stratigraphic intervals yielded U-Pb ages of $1299 \pm 8$ to $1238 \pm 22 \mathrm{Ma}$ [9], indicating that supracrustal rocks are coeval with 1282-1248 Ma arc-related magmatism of the Losee Suite.

Termination of arc-related magmatism and closure of the back-arc basin took place at ca. $1200 \mathrm{Ma}$ during west-directed orogenic convergence. Subsequent lithospheric delamination, and ponding of asthenospheric melt at the base of the crust, provided a heat source for extensive crustal melting and the production of widespread and abundant synorogenic Fe-rich, metaluminous, A-type magmatism of the Byram and Lake Hopatcong Intrusive Suites that yielded U-Pb zircon ages of $1188 \pm 5$ to $1182 \pm 11 \mathrm{Ma}[9]$.

Late- to post-orogenic magmatism in the New Jersey Highlands is also dominated by metaluminous A-type magmatism that includes weakly deformed syenogranite (U-Pb zircon age of $1027 \pm 6 \mathrm{Ma}$ ) and undeformed Mount Eve Granite (U-Pb zircon age of $1019 \pm 5 \mathrm{Ma}$ ) [9]. The latter is characterized by sharp, discordant contacts and xenoliths of foliated country rocks. Post-orogenic magmatism also consists of small volumes of regionally widespread, undeformed granite pegmatite that yielded U-Pb zircon ages of $1004 \pm 3$ to $986 \pm 4 \mathrm{Ma}$ [11].

\section{Ottawan Metamorphic Conditions}

The Ottawan phase of the Grenvillian Orogeny in the New Jersey Highlands was characterized by west-directed compression, imbricate thrusting, crustal thickening, and granulite-facies metamorphism, supporting a continent-continent collisional tectonic setting [9]. The timing of this tectonothermal event in the Highlands is constrained by metamorphic overgrowths on zircon and monazite that yielded U-Pb ages of $1045 \pm 6$ to $1024 \pm 7 \mathrm{Ma}$ [9]. The penetrative NE-trending, SE-dipping planar metamorphic fabric and dominant northwest-verging isoclinal folds in the Mesoproterozoic rocks were formed during orogenic convergence and are therefore older than $1024 \mathrm{Ma}$. Emplacement of the Mount Eve Granite at 1019 Ma places a firm temporal constraint on the close of compressional orogenesis in the New Jersey Highlands and contiguous areas following continental collision.

Estimates of the metamorphic $T$ in the Highlands during Ottawan granulite facies metamorphism range from $670-780{ }^{\circ} \mathrm{C}$, from various geothermometers [10], and average $769^{\circ} \mathrm{C}$ based on regional calcite-graphite geothermometry [12]. Estimates of the confining $P$ during Ottawan metamorphism of the Highlands range widely from $\sim 410-700 \mathrm{MPa}$ from various geobarometers [10]. Young [7] calculated $T$ of $670-740^{\circ} \mathrm{C}$ using the garnet-biotite geothermometer, and $P$ ranging from $620-800 \mathrm{MPa}$ using the garnet-rutile-ilmenite-sillimanite-quartz geobarometer, from prismatine \pm kornerupine-bearing biotite gneiss at Mase Mountain (Figure 1). The author calculated $T$ of $720-737^{\circ} \mathrm{C}$ from the same location using the Ti-in-biotite geothermometer [13] and biotite compositions ( $\left.\mathrm{X}_{\mathrm{Mg}}=0.670-0.728, \mathrm{Ti}=0.311-0.324 \mathrm{apfu}\right)$ 
from Young [7]. Sonnenwald [14] calculated $T$ of $700-750^{\circ} \mathrm{C}$ based on garnet-biotite thermometry and $P$ ranging from $560-710 \mathrm{MPa}$ using the garnet-aluminosilicate-quartz-plagioclase geobarometer from biotite gneiss in the Hudson Highlands, north of the Ringwood location in New Jersey (Figure 1). Therefore, $P$ - $T$ estimates are $>600 \mathrm{MPa}$ and $670-750^{\circ} \mathrm{C}$ during Ottawan metamorphism of biotite gneiss whether or not it contains kornerupine and prismatine, comparable to the regional $P$ - $T$ estimates in the Highlands of $\sim 770{ }^{\circ} \mathrm{C}$ and $\geq 600 \mathrm{MPa}$ that are consistent with metamorphism to low- $P$ and high- $T$ granulite-facies conditions.

\section{Kornerupine-Bearing Gneiss}

\subsection{Field Relationships and Stratigraphy}

Outcrops of kornerupine-bearing gneiss in the New Jersey Highlands are present at two locations, one in the northeastern part of the Highlands at Ringwood and the other in the west-central part at Mase Mountain (Figure 1). The quartzofeldspathic paragneiss that hosts kornerupine at both locations is mapped as biotite-quartz-feldspar gneiss (referred to here as biotite gneiss or kornerupine-bearing biotite gneiss), a unit that is both widespread and abundant in the Highlands [8]. Biotite gneiss consists of two main types that regionally occur in near equal abundance. The first type weathers light gray, pinkish gray, or pinkish white, and is light greenish gray or pinkish gray on fresh surfaces, whereas the second type weathers rusty and is greenish gray or gray on fresh surfaces (Figure 2). Both types are medium grained, display a penetrative planar metamorphic fabric defined mainly by biotite, and contain conformable, gradational interlayers of feldspathic quartzite generally $<2 \mathrm{~m}$ thick that have a similar mineral assemblage as the gneiss. Regionally, pinkish-gray and rusty types of biotite gneiss occur in close proximity, the significance of which is discussed in a later section. Migmatitic textures are commonly developed in both types of biotite gneiss, in which conformable layers of leucosome $<3 \mathrm{~m}$ thick have been transposed into the plane of high strain metamorphic fabric (Figure 2).

Biotite gneiss is present within a thick succession of supracrustal rocks composed of mafic metavolcanic rocks (amphibolite), felsic metavolcanic rocks (rhyolite gneiss), quartzofeldspathic and calc-silicate paragneisses, and marble that collectively underlie approximately $20-25 \%$ of the New Jersey Highlands [8,15]. Regionally, both pinkish-gray and rusty types of biotite gneiss maintain relatively consistent lithologic associations, and have conformable, sharp contacts with the units within this succession. The most common associations include: (1) locally pillowed mafic metavolcanic rocks of MORB and island-arc basalt affinity composed of hornblende + clinopyroxene + plagioclase + magnetite \pm orthopyroxene; (2) calc-silicate pyroxene paragneiss formed from a graywacke protolith and containing diopside + oligoclase + titanite + magnetite \pm quartz \pm calcite; and (3) a regionally thin calcitic marble unit $<70 \mathrm{~m}$ thick that locally occurs as two discrete layers [10]. The sequence of amphibolite, pyroxene gneiss and both rusty and non-rusty biotite gneiss repeats throughout the stratigraphy, not due to structural repetition, but rather as a result of alternating sequences of volcanism and sedimentation. 

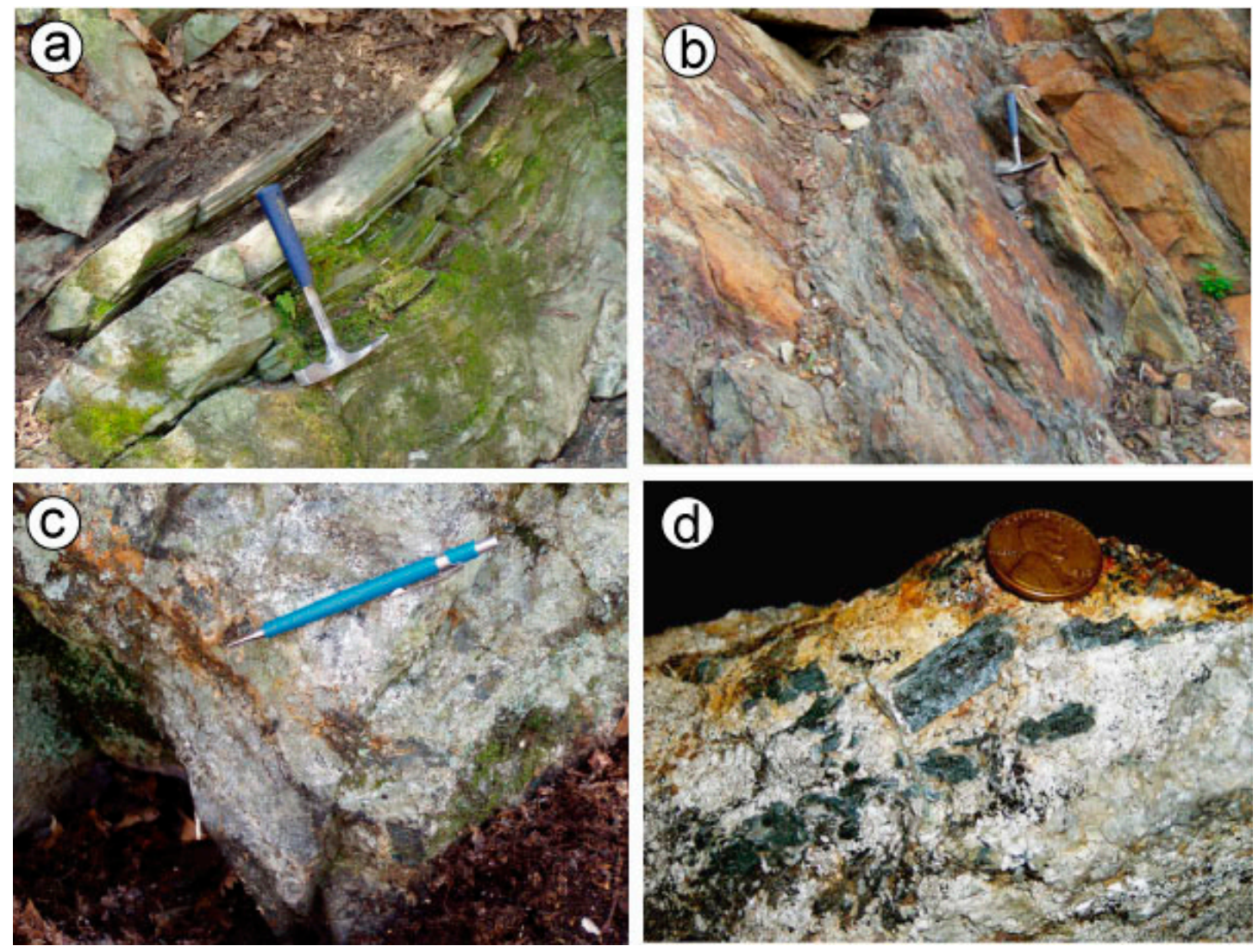

Figure 2. Field photographs of representative types of biotite gneiss in the New Jersey Highlands. (a) Interlayered sequence of pale pinkish-white metapelite (above hammer handle) and metagraywacke (beneath hammer head). Photograph is oriented SW (left) to NE (right). (b) Rusty graphitic biotite gneiss similar to that hosting prismatine + kornerupine at Mase Mountain. Photograph is oriented W (left) to E (right). Hammer is $33 \mathrm{~cm}$. (c) Pale pinkish-white kornerupine-bearing metagraywacke from Ringwood. Photograph is oriented NW (left) to SE (right). Pencil is $14.5 \mathrm{~cm}$. (d) Close-up of dark green, rectangular kornerupine crystals from Ringwood (below coin; $1.9 \mathrm{~cm}$ ), the longest of which is $2.5 \mathrm{~cm}$. Other minerals include quartz, oligoclase, microcline, and biotite. Note the occurrence of kornerupine in coarse-grained leucosome, and gradational contact between leucosome and host gneiss in lower right of photograph.

It is also worth noting that throughout the Highlands biotite gneiss is closely spatially associated with magmatic arc-related lithologies of the Losee Suite, most commonly tonalite gneiss (Figure 3). Primary igneous and sedimentary contacts between biotite gneiss and lithologies of the Losee Suite are not preserved and were modified during high-grade Ottawan metamorphism.

\subsubsection{Ringwood Location}

At Ringwood, kornerupine is present in pinkish-gray, quartz-rich biotite gneiss that strikes NE and forms a continuous layer as much as several $\mathrm{km}$ long that is spatially associated with pyroxene gneiss (Figure 3a). The latter is interlayered with, or contains, thin to thick, conformable clots, lenses, and layers of dark green, medium-grained, nearly monomineralic rock containing diopside. Tonalite gneiss and diorite gneiss of the Losee Suite crop out north and south of these units (Figure 3a). Several low-Ti magnetite deposits hosted by tonalite gneiss and amphibolite occur about $0.5 \mathrm{~km}$ north of the kornerupine-bearing biotite gneiss. Kornerupine at Ringwood locally occurs as small disseminated grains in biotite gneiss, but also occurs in a thin conformable layer of leucosome that has gradational contacts with and is mineralogically similar to the host gneiss. The leucosome contains dark greenish-gray prismatic crystals of kornerupine as long as $2.5 \mathrm{~cm}$ that are aligned parallel to the 
metamorphic fabric (Figure 2). The kornerupine- bearing layer at Ringwood is on the north side of a hinge developed in an upright ENE-plunging synform (Figure 3a) that deforms the Ottawan planar metamorphic fabric.

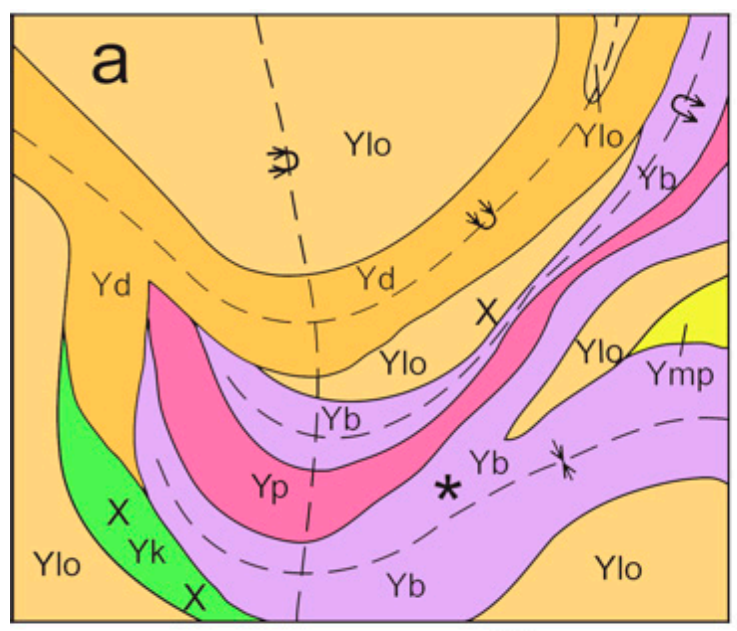

0

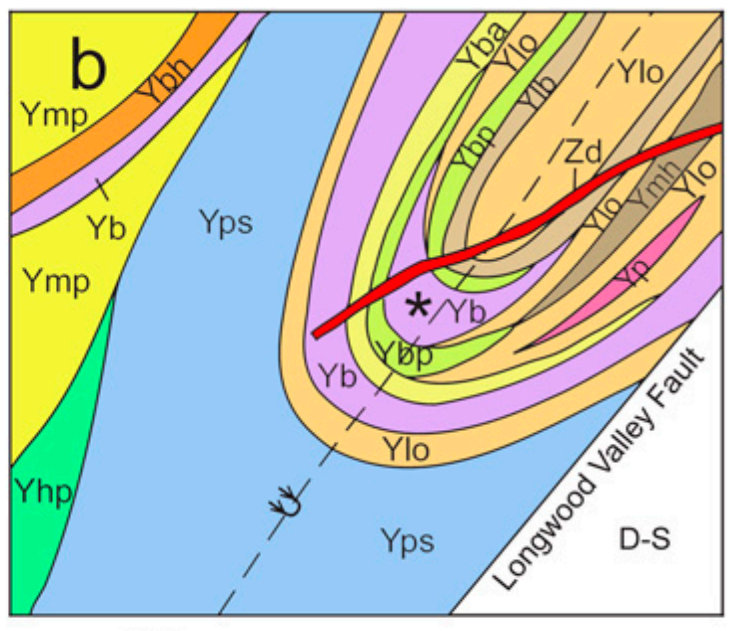

$1 \mathrm{Km}$

Figure 3. (a) Bedrock geology of the southeastern part of the Greenwood Lake 7.5-minute quadrangle [16] showing geologic relationships at the Ringwood kornerupine location. (b) Bedrock geology of the western part of the Dover 7.5-minute quadrangle [17] showing geologic relationships at the Mase Mountain kornerupine + prismatine location. Abbreviations: asterisk, kornerupine location; $\mathrm{X}, \mathrm{Fe}$-Ti oxide deposit; $\mathrm{Yb}$, biotite gneiss; Yp, pyroxene gneiss; $\mathrm{Yk}$, rhyolite gneiss; Ymp, clinopyroxene-quartz-feldspar gneiss; Ylo, tonalite gneiss; Yd, diorite gneiss; Ybp and Yhp, meta-anorthosite gneiss; Yps, clinopyroxene syenite; Yba, microperthite alaskite; Ybh, hornblende granite; D-S, undivided Devonian and Silurian cover rocks. Dashed lines show trace of axial surface of folds that deform Ottawan metamorphic fabric. See Figure 1 for location of Figure 3a,b.

\subsubsection{Mase Mountain Location}

At Mase Mountain, prismatine \pm kornerupine is present in rusty, quartz-poor biotite gneiss that strikes NE and is spatially associated with pyroxene gneiss, other quartzofeldspathic gneisses, a thin layer of meta-anorthosite, tonalite gneiss of the Losee Suite, and granite to syenite of the Byram and Lake Hopatcong Suites (Figure 3b). Compared to Ringwood, biotite gneiss here is thinner and more discontinuous along strike. Several prismatine \pm kornerupine-bearing layers $1-5 \mathrm{~cm}$ thick are present in biotite gneiss at Mase Mountain [7], where they are located in the hinge of a NW-verging NE-plunging synform (Figure 3b). Prismatine forms prismatic crystals $1-2 \mathrm{~cm}$ long, and locally as long as $6 \mathrm{~cm}$, that are aligned parallel to the metamorphic fabric. A single kornerupine crystal analyzed from this location is $3 \mathrm{~cm}$ long [7]. It is unclear if the coarser grains here are present in the host gneiss or in leucosome.

Overall, the principal differences in the geological relationships between the Ringwood and Mase Mountain occurrences are the quartz poor, rusty, graphitic host gneiss at Mase Mountain compared to the more siliceous pinkish-gray gneiss at Ringwood, the proximal association of kornerupine gneiss and meta-anorthosite at Mase Mountain and the absence of anorthositic rocks at Ringwood, and the absence of nearby low-Ti magnetite deposits at Mase Mountain that are present at Ringwood.

\subsection{Mineralogy}

The prograde mineral assemblages of pinkish-gray and rusty types of biotite gneiss are similar and characterized by polygonal grain boundaries suggesting that the minerals are in textural equilibrium. The mineral assemblages include garnet $(1-2 \%)+$ biotite $(1-19 \%)+$ plagioclase $(3-68 \%)+$ K-feldspar $(10-70 \%)+$ quartz $(4-61 \%) \pm$ sillimanite \pm ilmenite \pm rutile \pm apatite $[7,18,19]$. Graphite and pyrrhotite 
occur only in the type that weathers rusty, as well as in quartzite interlayers in rusty biotite gneiss. As noted, kornerupine is present as euhedral to subhedral grains in both pinkish-gray gneiss at Ringwood and in rusty gneiss at Mase Mountain. An X-ray diffraction pattern of the kornerupine from Ringwood is shown in Figure 4. At Mase Mountain, kornerupine is subordinate in abundance to prismatine [7]. Kornerupine is unzoned and contains inclusions of rutile, biotite, and feldspar, whereas prismatine is very weakly zoned (higher $\mathrm{Al}$ and lower $\mathrm{Si}, \mathrm{Fe}, \mathrm{Mn}$ from core to rim) and contains inclusions of rutile, ilmenite, biotite, sillimanite, and feldspar [7]. At Mase Mountain, textural evidence is absent for the growth of prismatine from precursor tourmaline or other borosilicate minerals [7]. Additional work is necessary to determine if borosilicate minerals other than kornerupine are present in biotite gneiss at Ringwood. No borosilicate minerals were recognized in biotite gneiss in the study by Sonnenwald [14] north of Ringwood. Garnet in biotite gneiss forms anhedral grains that are weakly zoned, and contain small inclusions of rutile, biotite, ilmenite, and sillimanite [7]. All garnets are Fe-Mg-rich and range from 51-65\% almandine and 23-42\% pyrope calculated by the author from data in other studies [7,14]. Biotite forms unzoned grains aligned parallel to the planar metamorphic fabric. It contains high $\mathrm{TiO}_{2}$ at Mase Mountain (5.6-5.8 wt. \%) and in the Hudson Highlands (4.36-7.33 wt. \%), and ranges from $\mathrm{Mg}$-rich $\left(\mathrm{FeO}=11-17\right.$ wt. $\left.\% ; \mathrm{X}_{\mathrm{Mg}}=0.69 \pm 0.03\right)$ to somewhat more Fe-rich $\left(\mathrm{FeO}=19-21 \mathrm{wt} . \% ; X_{\mathrm{Mg}}=0.57 \pm 0.06\right)[7,14]$. Feldspars consist of variable proportions of plagioclase and K-feldspar. Plagioclase forms euhedral to subhedral grains with polysynthetic twinning that have the composition of oligoclase $\left(A n_{21}-A n_{30}\right)$ to andesine $\left(A n_{30}-A n_{33}\right)$. K-feldspar occurs as anhedral to subhedral grains of locally mesoperthitic, microperthitic, and non-perthitic microcline to orthoclase. Sillimanite, rutile, and graphite, where present, form disseminated grains in the matrix that are mainly aligned parallel to the planar metamorphic fabric $[7,14,18]$. Although cordierite occurs locally in biotite gneiss in the Hudson Highlands north of New Jersey, [20], it is not recognized in biotite gneiss or in other Mesoproterozoic rocks in the New Jersey Highlands.

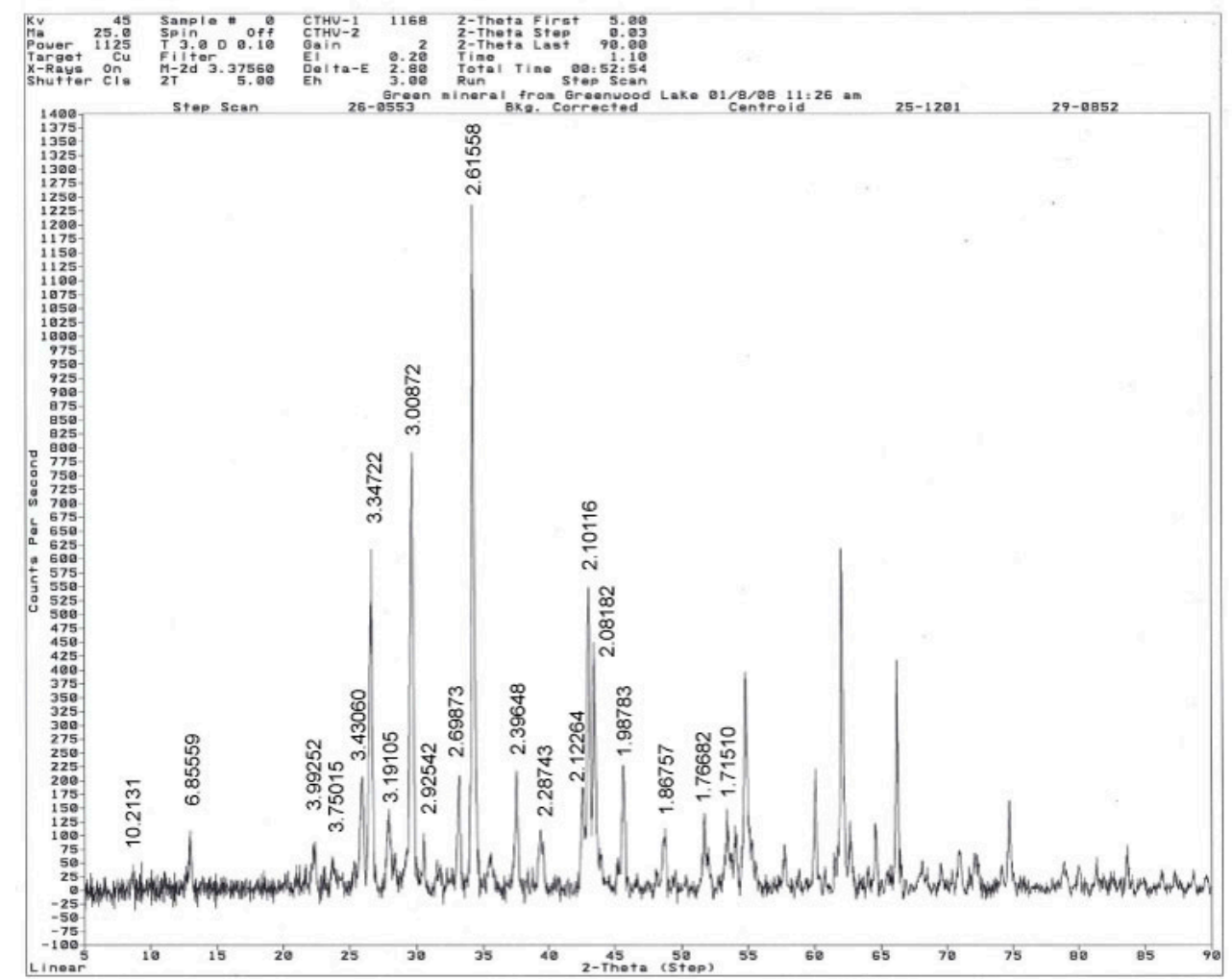

Figure 4. X-ray diffraction pattern of kornerupine from Ringwood showing the principal index peaks and their d-spacing (vertical values). 


\subsection{Protolith Geochemistry}

Major and selected trace element data of biotite gneiss from the Ringwood and Mase Mountain kornerupine locations were obtained from previous studies in the New Jersey Highlands and are presented in Table 1. Although interpretations herein rely mainly on major elements due to limited trace element data available, studies have shown that at metamorphic conditions up to granulite facies, major elements and most trace elements are redistributed and the process is essentially isochemical [21,22]. Therefore, it is proposed that inferences drawn from major elements and selected major and trace element ratios are valid.

Table 1. Geochemical composition of kornerupine-bearing biotite gneiss from the New Jersey Highlands.

\begin{tabular}{ccccccccccc}
\hline Sample & $\mathbf{R 1}$ & $\mathbf{R 1 6}$ & $\mathbf{1 2}$ & $\mathbf{3 0}$ & $\mathbf{1 3}$ & $\mathbf{T 1}$ & $\mathbf{T 2}$ & $\mathbf{T 5}$ & UCC & PAAS \\
\hline wt. $\%$ & & & & & & & & & & \\
\hline $\mathrm{SiO}_{2}$ & 62.30 & 63.68 & 64.30 & 65.90 & 67.60 & 53.35 & 53.80 & 56.00 & 66.60 & 62.80 \\
$\mathrm{TiO}_{2}$ & 0.72 & 0.87 & 0.86 & 0.72 & 0.71 & 1.81 & 1.26 & 1.07 & 0.64 & 1.00 \\
$\mathrm{Al}_{2} \mathrm{O}_{3}$ & 15.80 & 16.23 & 16.30 & 16.10 & 13.80 & 26.14 & 24.20 & 23.80 & 15.40 & 18.90 \\
$\mathrm{Fe}_{2} \mathrm{O}_{3}{ }^{*}$ & 5.74 & 5.86 & 7.52 & 2.81 & 4.63 & 2.18 & 7.32 & 3.33 & 5.00 & 7.22 \\
$\mathrm{MnO}$ & 0.03 & 0.06 & 0.04 & 0.01 & 0.02 & 0.01 & 0.05 & 0.01 & 0.10 & 0.11 \\
$\mathrm{MgO}$ & 2.44 & 2.94 & 2.86 & 2.61 & 1.86 & 3.95 & 3.75 & 2.67 & 2.48 & 2.20 \\
$\mathrm{CaO}$ & 1.24 & 1.69 & 2.06 & 1.66 & 2.00 & 1.93 & 1.03 & 1.05 & 3.59 & 1.30 \\
$\mathrm{Na}_{2} \mathrm{O}$ & 2.47 & 3.87 & 2.77 & 6.37 & 3.34 & 3.25 & 3.64 & 4.87 & 3.27 & 1.20 \\
$\mathrm{~K}_{2} \mathrm{O}$ & 7.37 & 2.65 & 3.15 & 3.32 & 4.34 & 5.89 & 3.66 & 5.28 & 2.80 & 3.70 \\
$\mathrm{P}_{2} \mathrm{O}_{5}$ & 0.16 & 0.09 & 0.08 & 0.13 & 0.18 & n.d. & n.d. & n.d. & 0.15 & 0.16 \\
$\mathrm{LOI}$ & 1.10 & 0.77 & 0.47 & 0.31 & 0.54 & 0.46 & 0.90 & 1.20 & n.d. & 6.00 \\
$\mathrm{Total}$ & 99.79 & 98.71 & 100.41 & 99.94 & 99.02 & 98.29 & 98.58 & 97.75 & 100.05 & 104.59 \\
\hline $\mathrm{ppm}$ & & & & & & & & & & \\
\hline $\mathrm{Ba}$ & 1549 & 623 & 570 & 440 & 710 & n.d. & 707 & 1030 & 628 & 650 \\
$\mathrm{Rb}$ & 237 & 100 & 150 & 130 & 160 & n.d. & 141 & 234 & 82 & 160 \\
$\mathrm{Sr}$ & 69 & 94 & 90 & 100 & 120 & n.d. & 138 & 156 & 320 & 200 \\
$\mathrm{Nb}$ & 15 & 11 & $<10$ & 20 & $<10$ & n.d. & 36 & 23 & 12 & 18 \\
$\mathrm{Cr}$ & 60 & 70 & 89 & 84 & 70 & n.d. & n.d. & n.d. & 92 & 100 \\
$\mathrm{Y}$ & 41 & 42 & 50 & 60 & 10 & n.d. & 116 & 87 & 21 & 27 \\
$\mathrm{Zr}$ & 212 & 248 & 210 & 200 & 180 & n.d. & 347 & 243 & 193 & 210 \\
$\mathrm{~B}$ & n.d. & n.d. & n.d. & n.d. & n.d. & 276 & 519 & 416 & 17 & 114 \\
$\mathrm{SiO}_{2} / \mathrm{Al}_{2} \mathrm{O}_{3}$ & 3.94 & 3.92 & 3.94 & 4.09 & 4.90 & 2.04 & 2.22 & 2.35 & 4.32 & 3.32 \\
$\mathrm{Al}_{2} \mathrm{O}_{3} / \mathrm{TiO}$ & 21.94 & 18.65 & 18.95 & 22.36 & 19.44 & 14.44 & 19.21 & 22.24 & 24.06 & 18.90 \\
$\mathrm{~K}_{2} \mathrm{O} / \mathrm{Al} \mathrm{O}_{3}$ & 0.47 & 0.16 & 0.19 & 0.21 & 0.31 & 0.22 & 0.15 & 0.22 & 0.18 & 0.19 \\
$\mathrm{ICV}$ & 1.27 & 1.11 & 1.18 & 1.09 & 1.22 & 0.72 & 0.82 & 0.75 & n.d. & n.d. \\
$\mathrm{CIA}$ & 52 & 57 & 58 & 49 & 50 & 63 & 67 & 60 & n.d. & n.d. \\
\hline
\end{tabular}

$\mathrm{Fe}_{2} \mathrm{O}_{3}{ }^{*}$, total $\mathrm{Fe}$ as $\mathrm{Fe}_{2} \mathrm{O}_{3}$; LOI, loss on ignition; n.d., not determined. ICV, Index of Compositional Variability and CIA, Chemical Index of Alteration (see text for explanation). Data: R1, R16 [19] and 12, 30, 13 [15] are metagraywacke from Ringwood location; T1, T2, T5 [7] are metapelite from Mase Mountain location. UCC, average upper continental crust [23]; PAAS, average post-Archean Australian shale [24].

Regionally, the geochemical composition of biotite gneiss is consistent with protoliths that were graywacke sandstone or pelite (Figure 5). Metagraywacke is characterized (in wt. \%; $1 \sigma$ uncertainty) by $\mathrm{SiO}_{2}=69.7 \pm 3.8, \mathrm{TiO}_{2}=0.60 \pm 0.1, \mathrm{Al}_{2} \mathrm{O}_{3}=14.0 \pm 1.4, \mathrm{MgO}=1.6 \pm 0.7, \mathrm{CaO}=1.7 \pm 1.1$, $\mathrm{Na}_{2} \mathrm{O}=3.4 \pm 1.2, \mathrm{~K}_{2} \mathrm{O}=3.9 \pm 1.5, \mathrm{Zr}=90-260 \mathrm{ppm}$, and $\mathrm{SiO}_{2} / \mathrm{Al}_{2} \mathrm{O}_{3}=3.9-4.9$. Compared to metagraywacke, metapelite has lower $\mathrm{SiO}_{2}(58 \pm 5.5)$, higher $\mathrm{TiO}_{2},(1.2 \pm 0.3), \mathrm{Al}_{2} \mathrm{O}_{3}(20.6 \pm 4.4)$, $\mathrm{MgO} 2.6 \pm 1.1)$, and $\mathrm{Zr}(210-490 \mathrm{ppm})$, and comparable $\mathrm{CaO}(1.6 \pm 0.8), \mathrm{Na}_{2} \mathrm{O}(3.0 \pm 1.5)$, and $\mathrm{K}_{2} \mathrm{O}$ $(4.9 \pm 2.4)$, and has $\mathrm{SiO}_{2} / \mathrm{Al}_{2} \mathrm{O}_{3}=2.0-2.3$ (Table 1). Values of $\mathrm{Cr}, \mathrm{Y}, \mathrm{Nb}, \mathrm{Ba}, \mathrm{Rb}$, and $\mathrm{Sr}$ overlap in both metagraywacke and metapelite, whereas $\mathrm{Y}$ is slightly higher in metapelite. Boron values are only available for metapelite from Mase Mountain and they range from 276-519 ppm in layers that contain prismatine \pm kornerupine [7]. The similarity of the major and trace element compositions of quartz-rich biotite gneiss (metagraywacke) to upper continental crust (UCC) [23] and of quartz-poor 
biotite gneiss (metapelite) to average post-Archean Australian shale (PAAS) [24] (Table 1), implies that their geochemical compositions do not differ significantly from that of their respective protoliths.

Both pinkish-gray and rusty types of biotite gneiss have geochemical compositions that range from metagraywacke to metapelite and that are essentially the same. Compared to metagraywacke, the elevated values of $\mathrm{Al}_{2} \mathrm{O}_{3}, \mathrm{TiO}_{2}$, and $\mathrm{Zr}$ in metapelite regionally likely reflect higher contents in the protolith of clay minerals, rutile + ilmenite, and zircon, respectively. However, the positive correlation of $\mathrm{Zr}$ with $\mathrm{TiO}_{2}$ (not shown) in samples of both quartz-rich and quartz-poor biotite gneiss suggests that zircon and rutile were locally deposited in the metagraywacke and metapelite protoliths as detrital heavy mineral phases. It is also worth noting that quartzite intercalated with biotite gneiss contains detrital zircons and high Zr values (190 ppm), mitigating against its origin as a chemical sediment.

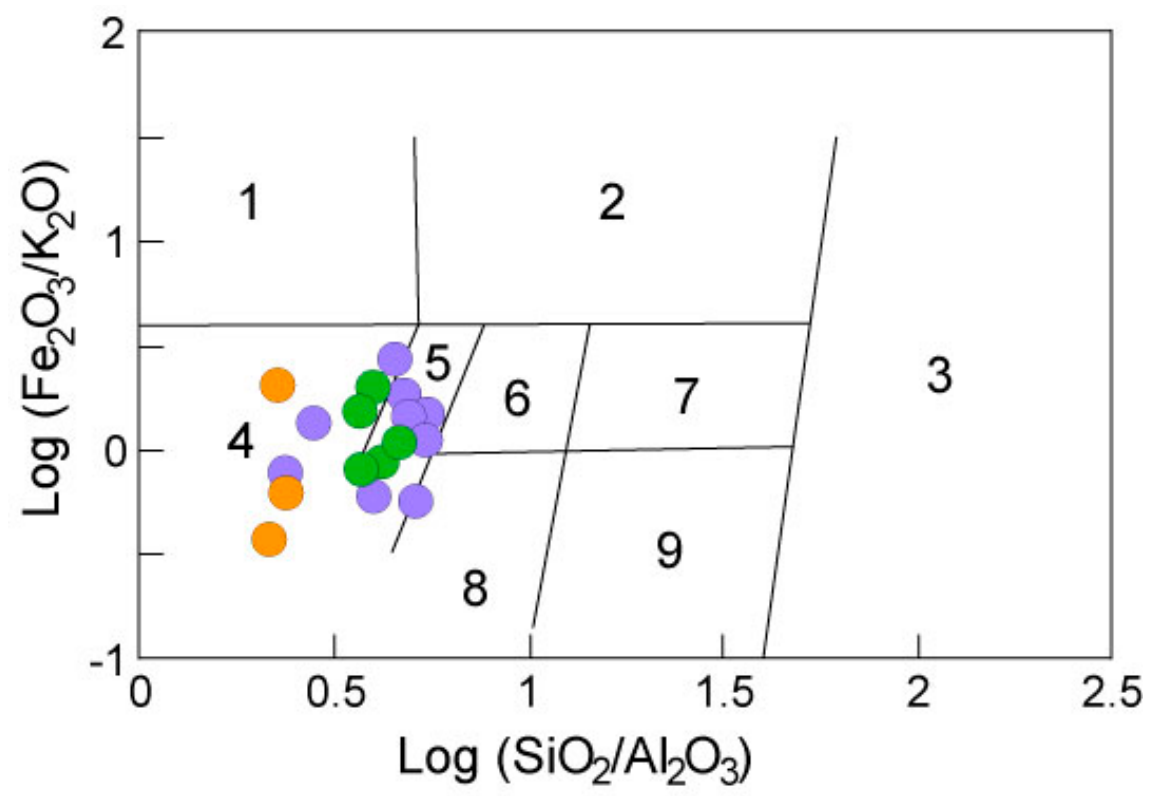

Figure 5. Geochemical classification of sedimentary rocks on the $\log \left(\mathrm{Fe}_{2} \mathrm{O}_{3} / \mathrm{K}_{2} \mathrm{O}\right)$ versus $\log$ $\left(\mathrm{SiO}_{2} / \mathrm{Al}_{2} \mathrm{O}_{3}\right)$ diagram [25] showing protolith compositions of kornerupine-bearing biotite gneiss from Ringwood (green circles), Mase Mountain (orange circles), and biotite gneiss without kornerupine from elsewhere in the New Jersey Highlands (blue circles) Fields: 1, Fe-shale; 2, Fe-sandstone; 3, quartz arenite; 4, shale; 5, wacke; 6, litharenite; 7 , sublitharenite; 8, arkose; 9, subarkose. Data from [7,15,19].

Weathering and Alteration

The amount of source-rock weathering of sediment in the protoliths of biotite gneiss was determined from the chemical index of alteration (CIA) [26], calculated as molar $\mathrm{Al}_{2} \mathrm{O}_{3} /\left(\mathrm{Al}_{2} \mathrm{O}_{3}+\right.$ $\left.\mathrm{CaO}^{*}+\mathrm{Na}_{2} \mathrm{O}+\mathrm{K}_{2} \mathrm{O}\right) \times 100$ where $\mathrm{CaO}^{*}$ is $\mathrm{Ca}$ in silicates only. Unweathered igneous rocks have CIA values of 45-55, shale of 70-75 and residual clays of 87-100, with high CIA values reflecting greater amounts of source weathering by quantifying the removal of $\mathrm{Ca}, \mathrm{Na}$, $\mathrm{K}$ in relation to $\mathrm{Al}$ [26]. Samples from Ringwood and Mase Mountain have low average CIA values of 54 and 62, respectively, comparable to regional values of 49-68 for pinkish-gray and rusty types of biotite gneiss (Figure 6). These values are indicative of generally low to moderate amounts of chemical weathering of the source. This inference is also supported by the weathering trends of average granite, tonalite and amphibolite source rock compositions from the Highlands on a ternary plot of $\mathrm{Al}_{2} \mathrm{O}_{3}-\left(\mathrm{CaO}^{*}\right.$ $+\mathrm{Na}_{2} \mathrm{O}$ ) $-\mathrm{K}_{2} \mathrm{O}$ (Figure 6). Chemical weathering reactions involving the destruction of plagioclase, or the effects of K-metasomatism, typically drive these trends to more potassic compositions along the A-K axis [26]. Samples of biotite gneiss plot on a linear trend toward the $\mathrm{Al}_{2} \mathrm{O}_{3}$ apex, from starting compositions between granite and tonalite along the plagioclase-K-feldspar join, reflecting low to moderate amounts of weathering of the source and the absence of K-metasomatism. The $\mathrm{K}_{2} \mathrm{O} / \mathrm{Na}_{2} \mathrm{O}$ ratio in biotite gneiss ranges from 0.5-5.1 in metagraywacke and 0.15-2.98 in metapelite, comparable 
to the average of 0.86 for UCC [23] and of 3.1 for PAAS [24], but a poor match for the high values of 3-117 reported from rocks that have experienced K-metasomatism [27].

\subsection{Provenance}

Ratios of elements that are sensitive discriminants of provenance and tectonic setting, such as $\mathrm{TiO}_{2}$ and $\mathrm{Cr}$ that serve as a proxy for a mafic source component and $\mathrm{Al}_{2} \mathrm{O}_{3}, \mathrm{Nb}$, and $\mathrm{Zr}$ for a felsic component [28], were used to identify geochemical characteristics of potential sediment sources for biotite gneiss. Based on data from Mesoproterozoic lithologies in the New Jersey Highlands [15], the $\mathrm{Ti} / \mathrm{Zr}$ and $\mathrm{Cr} / \mathrm{Nb}$ ratios are particularly useful source discriminants. Amphibolite and mafic orthogneiss have average $\mathrm{Ti} / \mathrm{Zr}=75$ and $\mathrm{Cr} / \mathrm{Nb}=46$, intermediate magmatic arc rocks (andesite and diorite gneiss) have $\mathrm{Ti} / \mathrm{Zr}=75$ and $\mathrm{Cr} / \mathrm{Nb}=8$, felsic magmatic arc rocks (tonalite gneiss) average 21 and 2.0, respectively, and supracrustal felsic orthogneiss (rhyolite gneiss) and potassic granites have $\mathrm{Ti} / \mathrm{Zr}=7$ and $\mathrm{Cr} / \mathrm{Nb}=0.64$. All types of biotite gneiss have overlapping ratios of $\mathrm{Ti} / \mathrm{Zr}(21.5 \pm 6)$ and $\mathrm{Cr} / \mathrm{Nb}(2.9 \pm 1.3)$ that are similar to ratios of felsic arc-related tonalite gneiss of the Losee Suite $(\mathrm{Ti} / \mathrm{Zr}=21, \mathrm{Cr} / \mathrm{Nb}=2)$, as well as of graywacke formed from arc-related detritus in an active continental margin or island-arc tectonic setting $(\mathrm{Ti} / \mathrm{Zr}=15-20, \mathrm{Cr} / \mathrm{Nb}=2.4-6)$ [28]. A felsic source for the protoliths of biotite gneiss is also suggested by the low abundances of $\mathrm{MgO}$ and $\mathrm{Cr}$ and high $\mathrm{Zr}$ in the unit regionally (Table 1). Provenance characterization using discriminant function analysis [29] yields similar results with biotite gneiss plotting in the active continental margin field that was receiving first-cycle sediment from a felsic igneous source having a geochemical affinity to granite/rhyolite and tonalite/dacite (Figure 7).

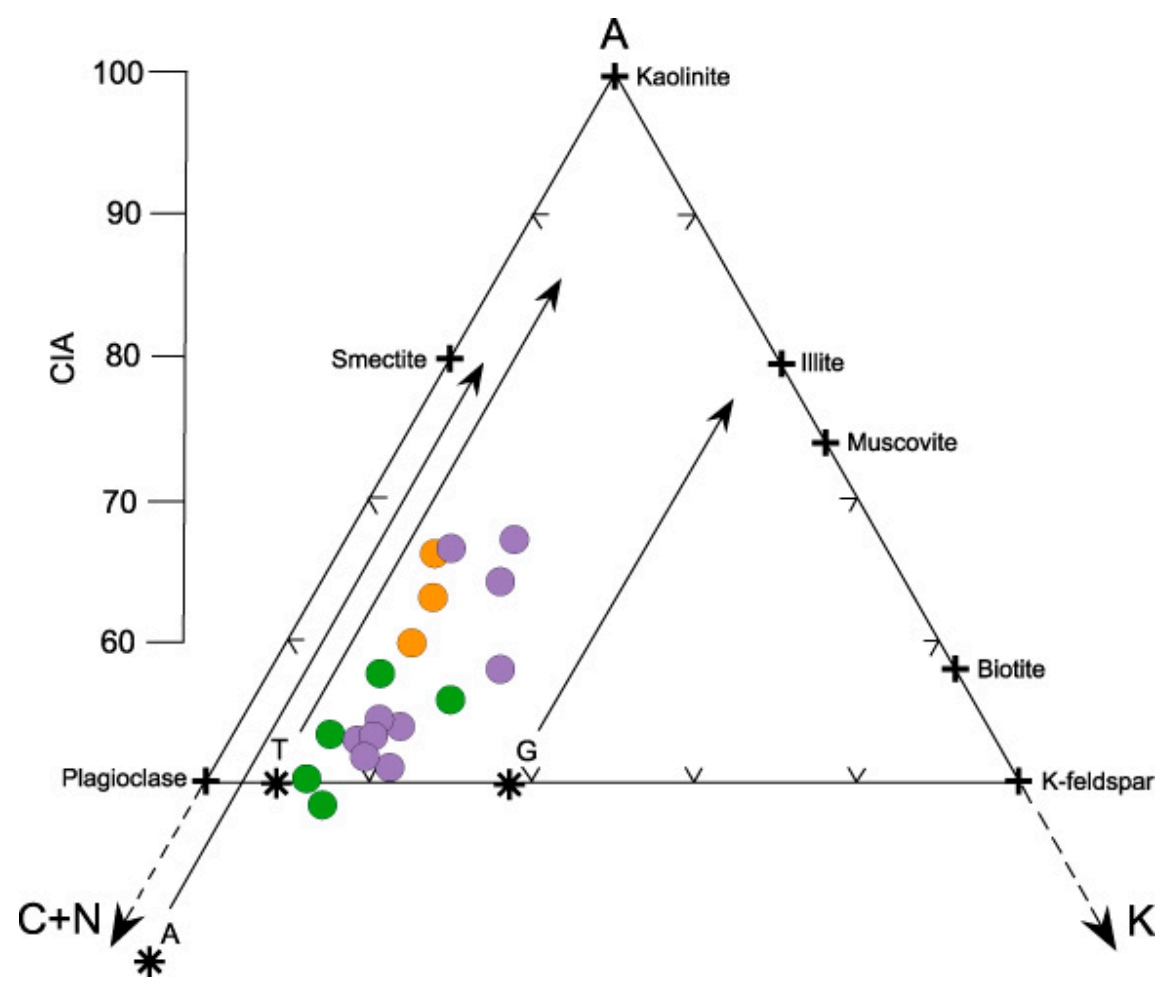

Figure 6. Molar Al-(Ca $+\mathrm{Na})-\mathrm{K}$ diagram [26] showing predicted weathering trends and chemical index of alteration (CIA) values for biotite gneiss from the New Jersey Highlands. Symbols as in Figure 5. Asterisks are average compositions of Mesoproterozoic granite $(\mathrm{G})$, tonalite (T), and amphibolite (A) from the Highlands [15]. 


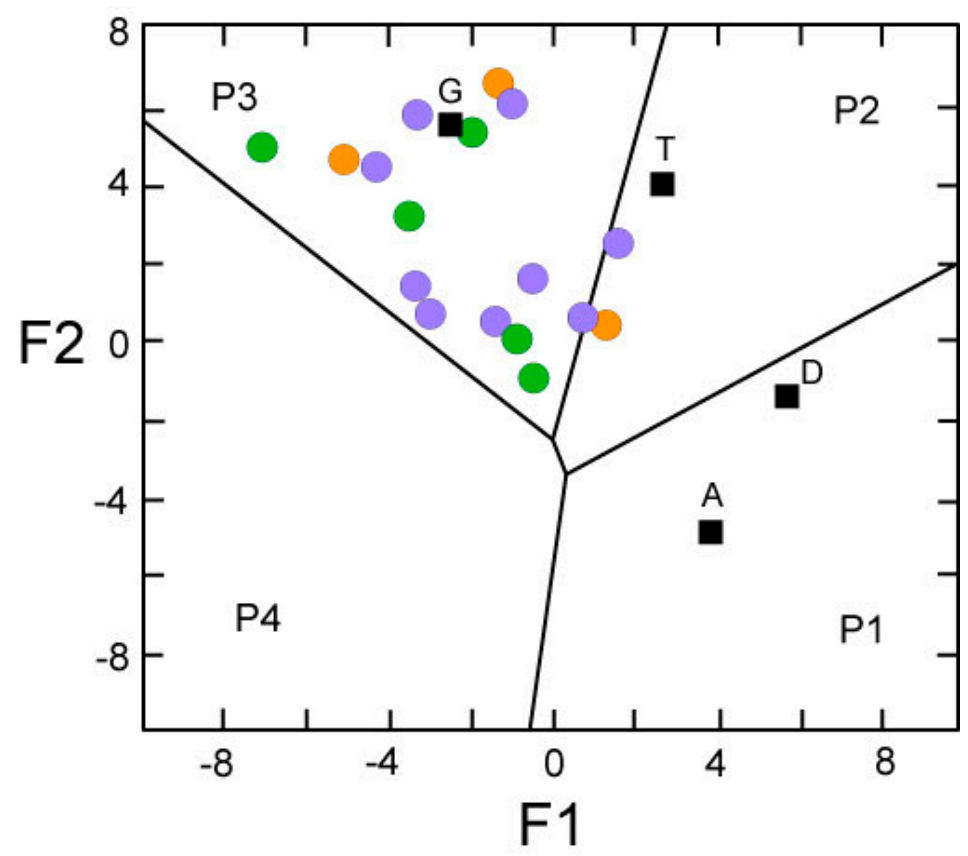

Figure 7. Plot of biotite gneiss from the New Jersey Highlands, and kornerupine-bearing variants of the gneiss from Ringwood and Mase Mountain, on a tectonic discrimination diagram [29]. F1 versus F2 calculated from discriminant function analysis using $\mathrm{Al}_{2} \mathrm{O}_{3}, \mathrm{TiO}_{2}, \mathrm{Fe}_{2} \mathrm{O}_{3}{ }^{\mathrm{T}}, \mathrm{MgO}, \mathrm{CaO}, \mathrm{Na}_{2} \mathrm{O}$, and $\mathrm{K}_{2} \mathrm{O}$. Fields: P1, Mafic Igneous Provenance; P2, Intermediate Igneous Provenance; P3, Felsic Igneous Provenance; P4, Quartzose Sedimentary Provenance. Average compositions of granite (G), tonalite (T), diorite (D), and amphibolite (A) are from the New Jersey Highlands [15]. Symbols as in Figure 5 .

The $\mathrm{Al}_{2} \mathrm{O}_{3} / \mathrm{TiO}_{2}$ ratio is also useful for source characterization because $\mathrm{Al}$ and Ti remain relatively immobile during sediment weathering and transport and thus reflect the $\mathrm{SiO}_{2}$ content and composition of the source [30]. The $\mathrm{Al}_{2} \mathrm{O}_{3} / \mathrm{TiO}_{2}$ ratio of biotite gneiss differs somewhat between metagraywacke $(23 \pm 4)$ and metapelite $(18 \pm 3)$, but this ratio is not significantly different between pinkish-gray gneiss $(23 \pm 4)$ and rusty gneiss $(20 \pm 6)$. The $\mathrm{Al}_{2} \mathrm{O}_{3} / \mathrm{TiO}_{2}$ ratio of biotite gneiss is comparable to that of felsic magmatic arc-related tonalite gneiss in the Highlands $(33 \pm 8)$ and supracrustal felsic orthogneiss and granite $(23 \pm 3)$ but differs from most other Mesoproterozoic lithologies. The significant increase in this ratio to values of $41-114$ in rocks of the Highlands having $>70 \mathrm{wt} . \% \mathrm{SiO}_{2}$ suggests that the felsic sediment source of biotite gneiss likely had a $\mathrm{SiO}_{2}$ content less than that.

Source heterogeneity and composition were also evaluated using ratios of $\mathrm{Zr} / \mathrm{TiO}_{2}$ and $\mathrm{Cr} / \mathrm{Al}_{2} \mathrm{O}_{3}$. Regionally, biotite gneiss has fairly uniform values of both ratios $\left(\mathrm{Zr} / \mathrm{TiO}{ }_{2}=1.45-5.46\right.$, $\mathrm{Cr} / \mathrm{Al}_{2} \mathrm{O}_{3}=0.03-0.08$ ) consistent with the derivation of sediments in the protoliths from a relatively homogeneous felsic source. Variability in these ratios would be indicative of a mixture of sediment sources, which is something not seen in the geochemical data between the Ringwood and Mase Mountain kornerupine locations or in biotite gneiss regionally.

The $\mathrm{K}_{2} \mathrm{O} / \mathrm{Al}_{2} \mathrm{O}_{3}$ ratio is a good measure of the proportion of clay minerals in the source versus silicates, such as feldspar and mica, with the ratio in clays $<0.3$ and in silicate phases 0.3-0.9 [31]. Regionally, biotite gneiss has fairly uniform $\mathrm{K}_{2} \mathrm{O} / \mathrm{Al}_{2} \mathrm{O}_{3}$ that ranges from $0.10-0.47$ in metagraywacke and $0.15-0.46$ in metapelite, reflecting a mixture of clay minerals and silicates in the sediment source of both protoliths. However, when applied to biotite gneiss at the two kornerupine locations, the $\mathrm{K}_{2} \mathrm{O} / \mathrm{Al}_{2} \mathrm{O}_{3}$ ratio at Mase Mountain is $0.20 \pm 0.04$ compared to $0.27 \pm 0.1$ at Ringwood, indicative of the higher clay content of the pelitic source at the former. This same result is seen using the Index of Compositional Variability (ICV) [31], calculated from wt. \% $\left(\mathrm{Fe}_{2} \mathrm{O}_{3}+\mathrm{K}_{2} \mathrm{O}+\mathrm{Na}_{2} \mathrm{O}+\mathrm{CaO}+\mathrm{MgO}+\right.$ $\left.\mathrm{MnO}+\mathrm{TiO}_{2}\right) / \mathrm{Al}_{2} \mathrm{O}_{3}$. The ICV is an indication of the compositional maturity of sediments, in which 
rocks containing abundant clay minerals have values $<1$ and rocks dominated by silicate minerals values $>1$. Kornerupine-bearing gneiss from Mase Mountain has an ICV of $0.76 \pm 0.05$ compared to $1.17 \pm 0.07$ from Ringwood and $1.05 \pm 0.19$ for biotite gneiss regionally, consistent with the somewhat higher clay content of the gneiss at Mase Mountain. Nevertheless, ICV values of all types of biotite gneiss regionally are indicative of the overall immaturity of the sediment source.

Collectively, the data suggest that sediments comprising the graywacke and pelitic protoliths of biotite gneiss are relatively immature, mainly first-cycle sediments that were derived from a relatively homogeneous source with a geochemical affinity to felsic arc-related rocks. This interpretation is supported by U-Pb detrital zircon ages of ca. 1349 and $1264 \mathrm{Ma}$ [32] obtained from a quartzite layer in biotite gneiss south of Ringwood that are comparable to ages of the Wanaque tonalite gneiss (1366-1363 Ma) and the Losee Suite (1282-1248 Ma) in the Highlands. Older detrital zircon populations from the quartzite reveal that sediments in the protolith were also derived from sources having ages of $1511 \mathrm{Ma}, 1639-1699 \mathrm{Ma}$, and $1778 \mathrm{Ma}$ [32]. Therefore, although the geochemical data are permissive of the Losee magmatic arc as constituting a proximal and geochemically suitable sediment source for the graywacke and pelite protoliths of biotite gneiss, the data also suggest that sediment input from older arc-related sources is also possible. Moreover, the elevated concentrations of detrital heavy minerals (rutile, ilmenite, zircon) in some samples of biotite gneiss also suggest that there may have been some input from mature, recycled sedimentary rocks having a continental affinity, although the contribution from such a source was likely minor.

\subsection{Depositional Environment}

The field relationships, lithological, geochemical, and isotopic characteristics of the supracrustal rocks provide important constraints for the depositional environment that prevailed during sedimentation of the protoliths of biotite gneiss. Two important points relevant to this issue are: (1) the thick sequences of intercalated metasedimentary and bimodal metavolcanic rocks in the western and eastern Highlands are coeval and formed as part of the same succession; and (2) the supracrustal succession was deposited in a back-arc basin setting on extended continental crust, inboard of the Losee magmatic arc (Figure 8). The first point is supported by the similar mineralogical and geochemical compositions, metamorphic grade, and U-Pb zircon ages of Mesoproterozoic lithologic units regionally, implying they are part of a single succession that was subsequently dismembered by faults $[9,10]$. The marine isotope signature of regional marble units has a restricted range of $\delta^{13} \mathrm{C}_{\text {carbonate values of }}$ -0.21 to $0.31 \%$ in the eastern Highlands [10] and $0.35 \pm 0.73 \%$ o in the western Highlands $[12,33]$ that reflect a common depositional environment and the preservation of protolith carbon isotope values. The second point is supported by the geochemical composition of supracrustal mafic metavolcanic rocks that are intercalated with quartzofeldspathic and calc-silicate paragneisses from different stratigraphic intervals within the succession that have an affinity to basalt formed in a back-arc tectonic setting $[9,10]$.

The widespread abundance in the Highlands of both pinkish-gray biotite gneiss and rusty graphitic gneiss also provides an important constraint for the depositional environment of the protoliths. Pinkish-gray and rusty types of gneiss formed from both pelite and graywacke protoliths alternate within the stratigraphy or occur within close proximity. Rusty biotite gneiss contains as much as $28 \mathrm{wt}$. \% total carbon as graphite that has $\delta^{13} \mathrm{C}$ values of $-22 \pm 3$ to $-26 \pm 2 \%$ o and is interpreted as having formed in situ through the metamorphism of colonies of microbial mats [18]. Although carbonaceous, sulfidic variants of biotite gneiss suggest deposition under reducing conditions in a restricted basin setting, the stratigraphic intercalation of pinkish-gray and rusty gneiss over short distances of $\geq$ tens of meters are more consistent with the periodic fluctuation of oxic and anoxic conditions in the same basinal setting. Deep open ocean environments do not favor the accumulation of organic matter [34]. Therefore, the anoxic conditions required for its preservation during deposition of the protolith of rusty biotite gneiss likely occurred in a shelf environment, but more distally than the carbonate platform. 


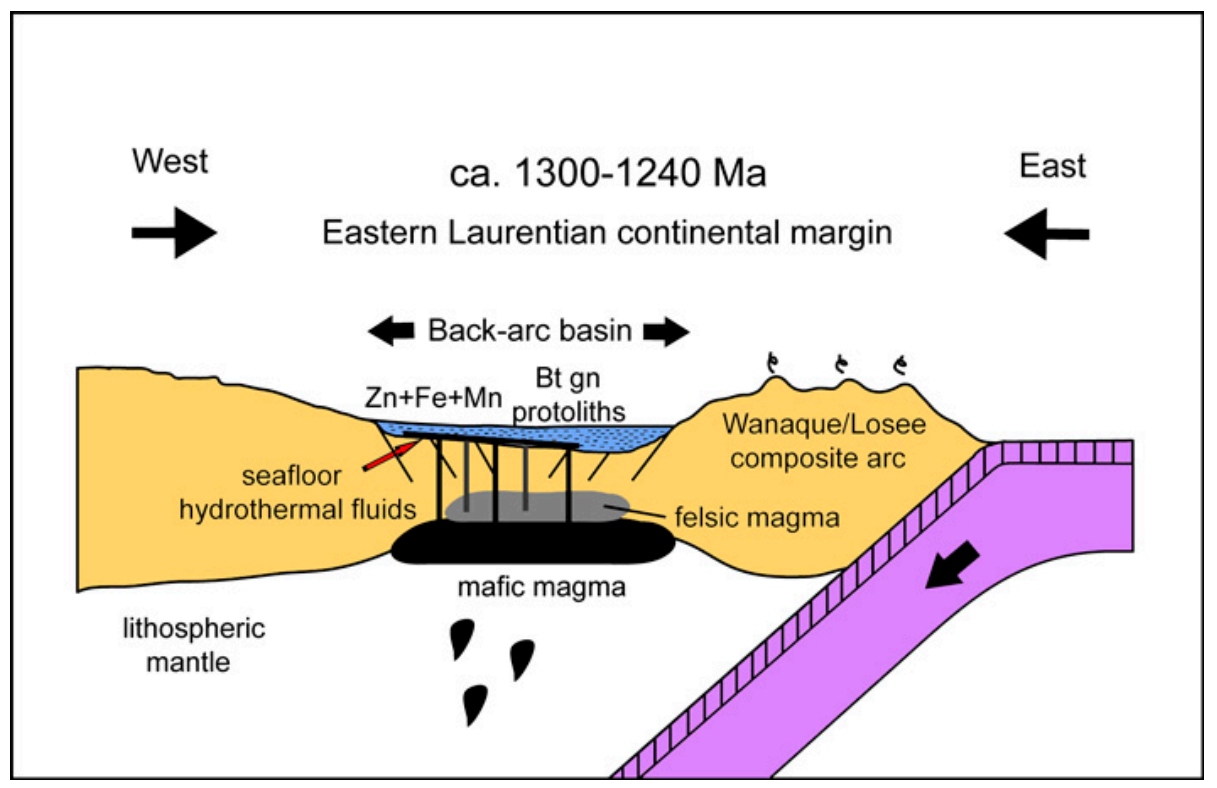

Figure 8. Tectonic setting of the New Jersey Highlands at ca. 1.3-1.24 Ga showing back-arc basin formed on extended crust inboard of the Wanaque/Losee continental margin arc [9]. Widespread hydrothermal activity driven by heat from shallow magma chambers beneath the back arc produced locally intense alteration in supracrustal metavolcanic rocks and precipitated Fe and Zn-Fe-Mn in carbonate protoliths on the seafloor. Metagraywacke and metapelite protoliths of biotite gneiss (Bt gn) hosting kornerupine + prismatine likely formed more distally from the influence of hydrothermal plumes. West and east refer to present coordinates.

In summary, similar geochemical compositions of biotite gneiss regionally, whether or not they contain kornerupine, argue strongly for lithologic variants of the gneiss as representing sedimentary facies of a common unit that was receiving sediment from the same, or a similar, felsic arc-related source. The presence of intercalated pelite and graywacke protoliths of the gneiss, their presence above spatially associated marble units, and their apparent facies relationship with calc-silicate gneiss, implies deposition under conditions of somewhat deeper water and more distally than the carbonate platform [9,10]. A U-Pb detrital zircon age of ca. $1264 \mathrm{Ma}$ from a quartzite layer within biotite gneiss a few km south of Ringwood provides a possible maximum depositional age for the unit [32]. Hence, biotite gneiss represents an interval of marine sedimentation and silting of the carbonate shelf in a back-arc basin setting along the eastern Laurentian margin at $>1200 \mathrm{Ma}$.

\section{Implications for the Source of Boron}

The absence of boron isotope data for kornerupine and other borosilicate minerals in biotite gneiss in the Highlands renders interpretations involving the source or sources of boron as speculative. Nevertheless, the geological relationships discussed above provide significant constraints for the source of boron and the timing of borosilicate formation in biotite gneiss. Potential sources of boron that are compatible with the geological relationships include: (1) mobilization of a B-rich fluid derived from metamorphism of a evaporite protolith; (2) selective replacement of Al-rich layers in the protoliths of biotite gneiss by a B-rich hydrothermal fluid; and (3) the breakdown of B-rich sediment(s) in the protoliths of biotite gneiss during Ottawan metamorphism. Other possible sources were dismissed, such as B-rich magmatic fluids derived from peraluminous granites due to the absence of peraluminous plutonic rocks in the Highlands, or the release of boron in arc-related tonalite, diorite, or rhyolite gneiss during Ottawan metamorphism based on uniformally low B values of $<10 \mathrm{ppm}$ (detection limit) in these lithologies. 


\subsection{Metamorphism of a Marine Evaporite Protolith}

It is well known that boron is an essential constituent of borate minerals present in evaporite deposits and that it may be mobilized as a component of a B-rich fluid during metamorphism of the protolith [35]. Although rocks of suitable bulk composition for an evaporite deposit are generally absent in the New Jersey Highlands, a sequence of dolomitic marble containing abundant Mg-rich phases (phlogopite, talc and serpentine), dravite-bearing paragneiss, and dravite-bearing quartzite that are interpreted to be a metaevaporite $[10,36]$ are present in a narrow, fault-bounded panel in the southwestern Highlands (Figure 9). However, even if this interpretation is correct, it is highly unlikely that a B-rich aqueous fluid mobilized from these rocks during high-grade metamorphism would have survived transport $>20 \mathrm{~km}$ to the nearest kornerupine location, making these rocks an unlikely source of boron in the protoliths of biotite gneiss.

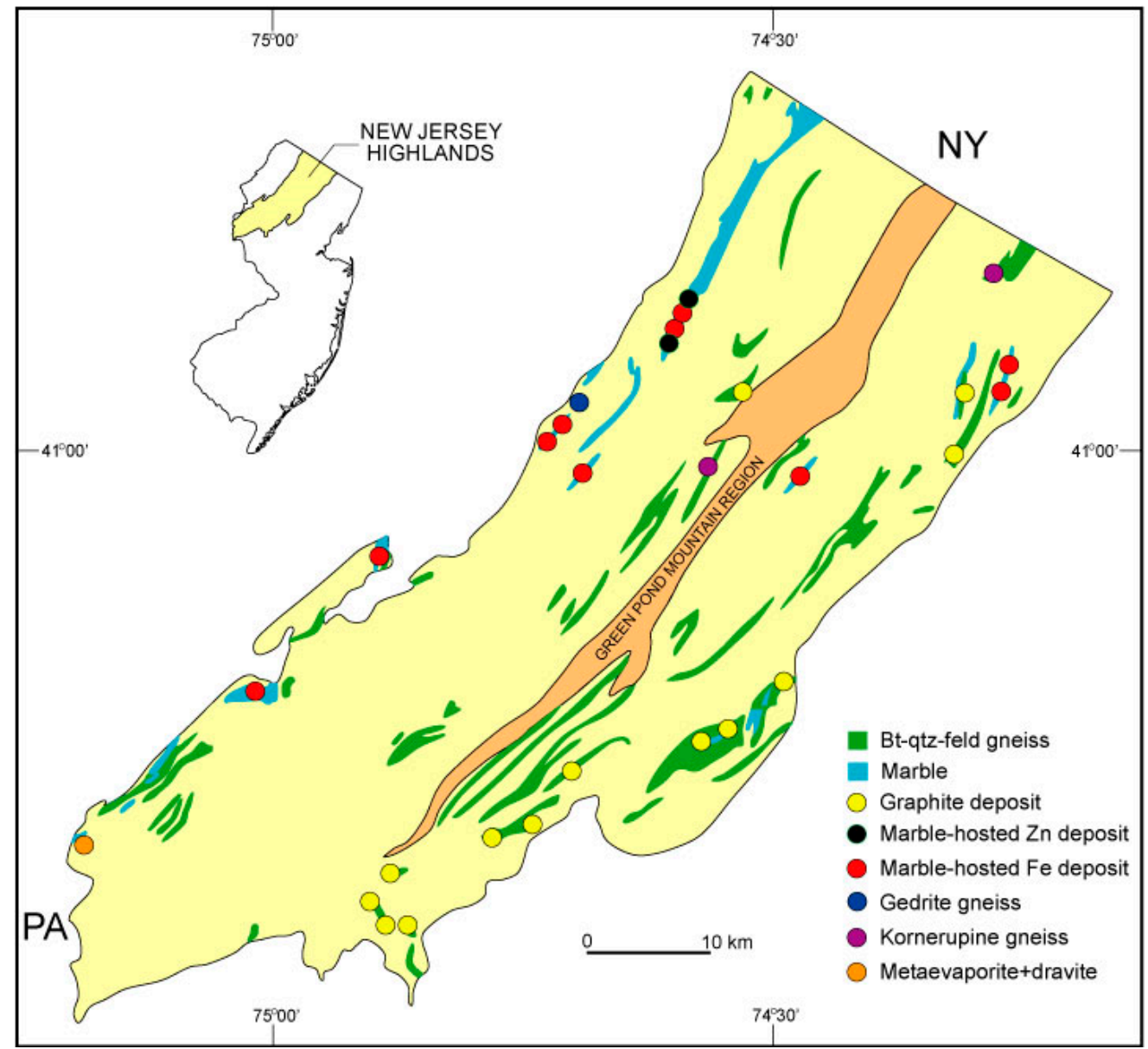

Figure 9. Map showing the distribution of marble in the New Jersey Highlands that hosts zinc deposits at Franklin and Sterling Hill and regional low-Ti magnetite deposits, biotite gneiss that hosts graphite deposits and the kornerupine + prismatine locations of this study, gedrite gneiss, and possible metaevaporite deposit. Note the linear trends of marble-hosted magnetite and zinc deposits in the western Highlands and confinement of graphite deposits mainly to the eastern Highlands. Modified from [18,33].

Elsewhere in the Highlands, marble layers in the eastern part of the region are mainly calcic and contain negligible amounts of $\mathrm{Fe}, \mathrm{Mg}$ and $\mathrm{Al}$, and thus are a poor match for an evaporite protolith. Marble in the northwestern Highlands very locally contains silicate-borate lenses 0.6 meters thick composed of sparse amounts of borosilicates (fluoborite, sinhalite, warwickite) [11]. These lenses have yielded $\delta^{11} \mathrm{~B}$ values of 1-2\% [37], unlike those of typical marine evaporites that average 25\%o [38]. 
Moreover, these lenses are undeformed and lack a penetrative metamorphic fabric, they contain zircon as an early part of the paragenetic sequence that yielded a U-Pb age of $1040 \pm 4 \mathrm{Ma}$ [11], and they crop out tens of $\mathrm{km}$ from the kornerupine locations at Ringwood and Mase Mountain, making them an unlikely source of boron in biotite gneiss. Therefore, although metaevaporitic rocks may be present locally in the western Highlands, they are absent in the remainder of the region, ruling them out as a viable source of boron with which to form kornerupine and prismatine in biotite gneiss.

\subsection{Replacement by B-Rich Hydrothermal Fluid}

The potential influence of a B-rich hydrothermal fluid in the formation of kornerupine + prismatine is supported by a mounting body of evidence indicating the presence of an extensive seafloor hydrothermal system between 1.3 and 1.2 Ga mainly in the present-day western New Jersey Highlands that was coeval with back-arc basin sedimentation and bimodal volcanism [9]. Mafic magma chambers beneath the back-arc (Figure 8) are interpreted as having supplied the heat that drove the hydrothermal system [9]. Marble-hosted Zn-Fe-Mn deposits at Franklin and Sterling Hill, and numerous low-Ti magnetite deposits, form linear belts (Figure 9) implying some degree of structural control of precursor metals along premetamorphic tectonic lineaments possibly related to extensional faulting in the back arc [39]. Stable isotope evidence suggests that Fe and $\mathrm{Zn}$ in the deposits were derived from low $T$ (ca. $\left.150{ }^{\circ} \mathrm{C}\right)[33,40]$ hydrothermal fluids that discharged on the seafloor and precipitated Fe as hydroxide and $\mathrm{Zn}$ as oxide, hydroxide, or silicate minerals in the carbonate protolith [33]. Hydrothermal influence in the back arc is also supported by the intense premetamorphic alteration of supracrustal metavolcanic rocks proximal to the Fe deposits and the absence of alteration in these metavolcanic rocks distal to the deposits (Figure 10) [33,39,41]. In addition, rare outcrops of Mg-rich gedrite-bearing orthogneiss that are along strike of the Fe and $\mathrm{Zn}$ deposits (Figure 9) display the same intense alteration as metavolcanic rocks proximal to the Fe deposits [41]. Gedrite-bearing rocks are interpreted as having formed during premetamorphic alteration of a basalt protolith in the back arc through low T (ca. $150-200{ }^{\circ} \mathrm{C}$ ) interaction with a hydrothermal fluid and seawater [41]. Another recent study [19] interpreted low-Ti Fe deposits near Ringwood (Figure 3a) that lack tourmaline or other borosilicate mineralization as having formed from exhalative fluids that discharged in the back arc, thus extending the same, or a temporally related, hydrothermal system into the eastern Highlands as well.

In marine hydrothermal systems, B-rich fluids may precipitate tourmaline through the preferential replacement of aluminous sediments in the protolith [42]. Bearing this in mind, the presence of a hydrothermal signature in biotite gneiss was evaluated using ratios of elements that quantify the contribution of a hydrothermal component $(\mathrm{Fe}, \mathrm{Mn})$ to a clastic component $(\mathrm{Al}, \mathrm{Ti})$ in the sedimentary protolith. The ratios of $\mathrm{Fe}+\mathrm{Mn} / \mathrm{Al}, \mathrm{Fe}+\mathrm{Mn} / \mathrm{Ti}, \mathrm{Ba} / \mathrm{Al}$, and $\mathrm{Ba} / \mathrm{Ti}$ are particularly useful in identifying hydrothermal input, with higher values indicating proximity to a vent source $[43,44]$. All variants of biotite gneiss have low $\mathrm{Fe}+\mathrm{Mn} / \mathrm{Al}(0.10-0.77), \mathrm{Fe}+\mathrm{Mn} / \mathrm{Ti}(1.3-10.1), \mathrm{Ba} / \mathrm{Al}(0.003-0.017)$, and $\mathrm{Ba} / \mathrm{Ti}$ (0.06-0.41) that overlap the average ratios of $0.44,9.4,0.008$, and 0.16 , respectively, in UCC. The same relationship is seen on a diagram of $\mathrm{Fe} / \mathrm{Ti}$ versus $\mathrm{Al} /(\mathrm{Al}+\mathrm{Fe}+\mathrm{Mn}$ ) (Figure 11) in which most samples of biotite gneiss cluster near the average compositions of pelagic sediment and UCC, although three samples, that include one from Mase Mountain, indicate possible hydrothermal input to the protolith. The Ishikawa alteration index $\left(\mathrm{AI}=100\left(\mathrm{~K}_{2} \mathrm{O}+\mathrm{MgO}\right) /\left(\mathrm{K}_{2} \mathrm{O}+\mathrm{MgO}+\mathrm{Na}_{2} \mathrm{O}+\mathrm{CaO}\right)\right.$ measures the dissolution of plagioclase and replacement by sericite and chlorite. Most samples of biotite gneiss have AI values ranging from 30-61 that overlap the fields of relatively unaltered igneous rocks $(\mathrm{AI}<60)$. Five samples, including one each from Ringwood and Mase Mountain, have AI values of 65-82 and display a similar chlorite-rich alteration vector as intensely altered supracrustal metavolcanic rocks in the Highlands (Figure 10). 


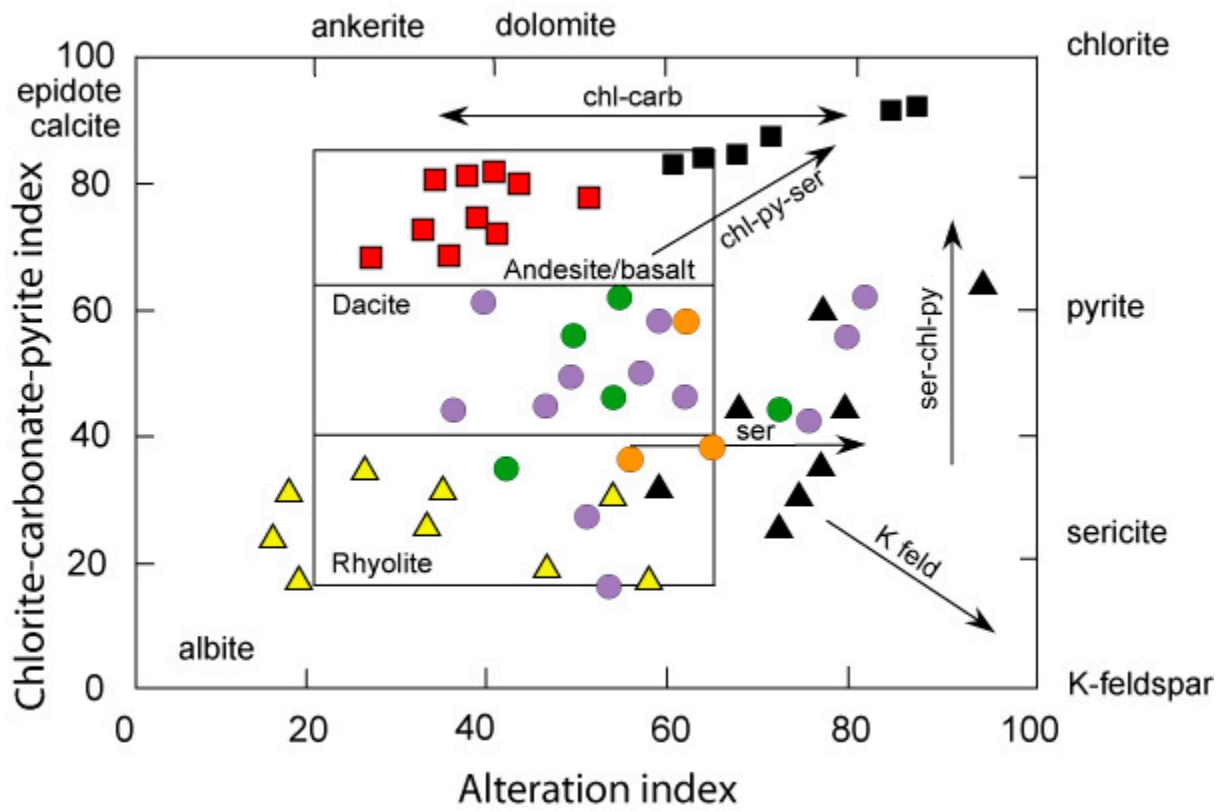

Figure 10. Alteration box diagram [45] showing hydrothermal alteration trends (solid arrows) in relation to unaltered felsic, intermediate and mafic igneous rocks (inset box). Bimodal supracrustal metavolcanic rocks proximal to magnetite deposits in the New Jersey Highlands plot along a trend characterized by moderate to severe chlorite-pyrite-sericite hydrothermal alteration, whereas metavolcanic rocks distal to the deposits are relatively unaltered $[33,41]$. Biotite gneiss plots mainly in the field of unaltered rocks, although five samples, including one each from Ringwood and Mase Mountain, show incipient alteration along the same trend as altered metavolcanic rocks. Red and black squares are unaltered and altered mafic metavolcanic rocks, respectively; yellow and black triangles are unaltered and altered felsic metavolcanic rocks, respectively Other symbols as in Figure 5. AI $=100\left(\mathrm{~K}_{2} \mathrm{O}+\mathrm{MgO}\right) /\left(\mathrm{K}_{2} \mathrm{O}+\right.$ $\left.\mathrm{MgO}+\mathrm{Na}_{2} \mathrm{O}+\mathrm{CaO}\right) . \mathrm{CCPI}=100\left(\mathrm{MgO}+\mathrm{FeO}^{*}\right) /\left(\mathrm{MgO}+\mathrm{FeO}^{*}+\mathrm{Na}_{2} \mathrm{O}+\mathrm{K}_{2} \mathrm{O}\right)$.

High concentrations of Ba from seafloor vent sources are also characteristic of hydrothermally altered marine sediments [44,46]. Biotite gneiss from Ringwood has $\mathrm{Ba}>620 \mathrm{ppm}$ (except for two samples having 440-570 ppm), and one sample has Ba of $1549 \mathrm{ppm}$, which is considerably higher than the UCC average of $628 \mathrm{ppm}$ [23]. Concentrations of Ba are also high in biotite gneiss at Mase Mountain, where it ranges from 700-1030 ppm [7], as well as in the gneiss regionally where all but four samples have Ba ranging from 900-1200 ppm [15]. Alternatively, the high Ba values in biotite gneiss may be an inherited source-related feature as Ba values in felsic arc-related rocks of the Losee Suite are as high as $1500 \mathrm{ppm}$ and in regional granitic rocks as high as $2400 \mathrm{ppm}$. The positive correlation of Ba with $\mathrm{K}_{2} \mathrm{O}$ (not shown) implies the control of Ba mainly by K-feldspar and biotite contents in biotite gneiss and, therefore, the high Ba values are more likely a source-related feature than a signature of hydrothermal input.

Although the collective evidence discussed above supports widespread hydrothermal activity in the back-arc between 1299 and $1238 \mathrm{Ma}$, the absent to minimal hydrothermal signature in biotite gneiss provides little support for the precipitation of kornerupine or prismatine through the infiltration of a B-rich hydrothermal fluid into the protoliths. 


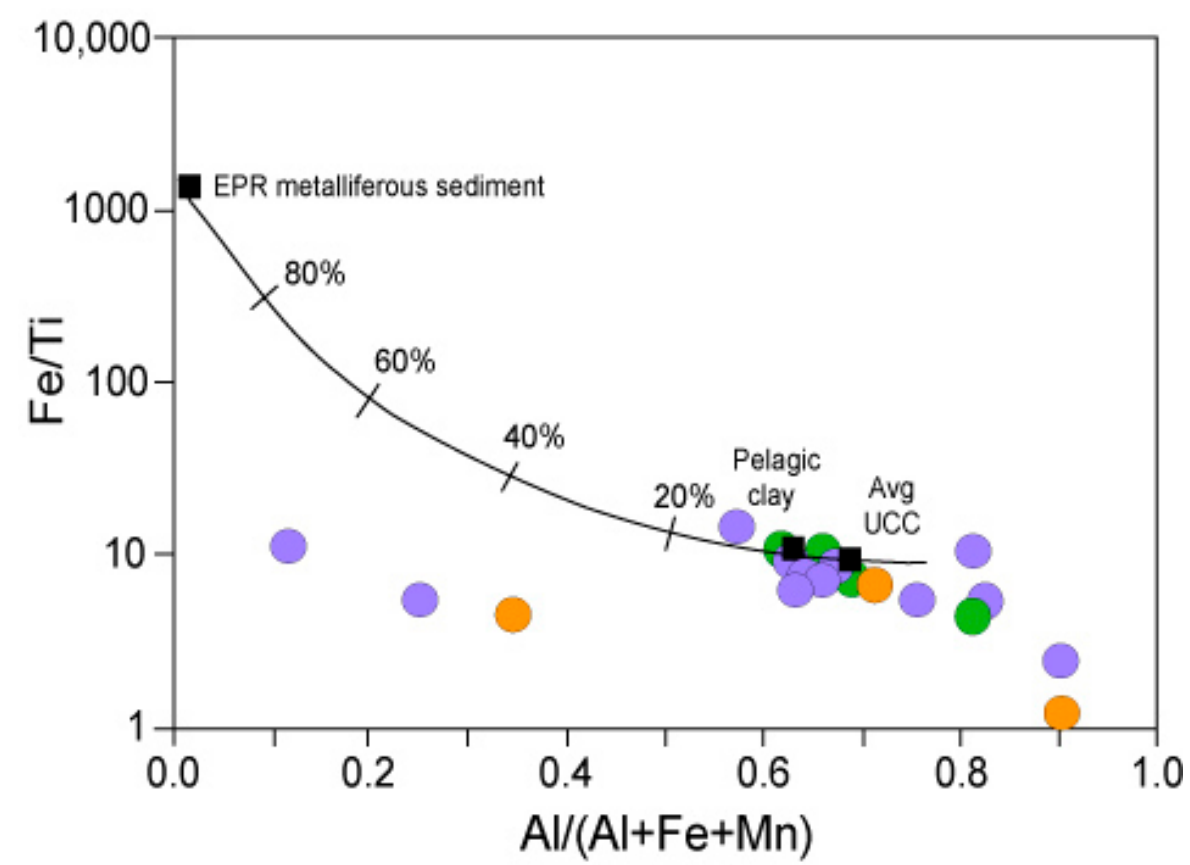

Figure 11. Plot of biotite gneiss from the New Jersey Highlands on a diagram of Fe/Ti versus $\mathrm{Al} / \mathrm{Al}$ $+\mathrm{Fe}+\mathrm{Mn}$ [43]. Numbers on curve represent percent of mixture of hydrothermal sediment (EPR metalliferous sediment) and clastic sediment (pelagic clay). Average upper continental crust (UCC) from [23]. Symbols as in Figure 5.

\subsection{Breakdown of B-Rich Sediments in the Protoliths during Metamorphism}

The derivation of boron through the synmetamorphic breakdown of local concentrations of B-rich clay or mica in the protoliths of biotite gneiss, as was proposed for the formation of prismatine and kornerupine at Mase Mountain [7], is supported by the geological relationships of biotite gneiss discussed above. This interpretation implies that B-bearing sediments were deposited in the protoliths sometime between ca. 1299-1238 Ma and were subsequently converted into the present high-grade borosilicate assemblage during Ottawan metamorphism at ca. 1045-1024 Ma. Both metagraywacke and metapelite protoliths reflect a mixture of clay minerals and silicates in the sediment source, so the presence of B-rich minerals such as illite or muscovite represent a viable source of boron. Although detrital tourmaline was ruled out as a source of boron at Mase Mountain from textural relationships based on optical petrography of prismatine [7], it may represent a suitable source of boron at Ringwood. More work is necessary to determine if it is present there in coexistence with kornerupine.

The precipitation of kornerupine and prismatine would require the retention of boron in the protoliths of biotite gneiss under granulite facies metamorphic conditions. Boron in tourmaline is stable at high metamorphic grade, but the breakdown of clays or micas due to dehydration reactions typically results in the progressive depletion of boron with increasing $T$ during prograde metamorphism [47]. Boron released during dehydration reactions may become a component of a B-rich fluid capable of precipitating tourmaline or borosilicates having characteristically low values of $\delta^{11} \mathrm{~B}$ [48]. In the New Jersey Highlands, the proximity of borosilicates at Ringwood and Mase Mountain to layers in biotite gneiss deformed by syn-Ottawan folding suggests the possibility of the structural control of these occurrences. If correct, then a B-rich fluid produced through the breakdown of B-bearing sediments during prograde Ottawan metamorphism may have migrated short distances in the host gneiss to more favorable structural sites where the borosilicates were then precipitated. This hypothesis is readily testable by sampling areas where syn-Ottawan folding has deformed biotite gneiss to search for additional sites of borosilicate mineralization. 


\section{Conclusions}

Rare occurrences of kornerupine \pm prismatine in the Grenvillian New Jersey Highlands are recognized in granulite-facies biotite paragneiss formed from graywacke and pelite protoliths. Geochemical indices of weathering and provenance are compatible with the derivation of the protoliths from relatively immature and unweathered first-cycle sediment from a felsic arc-related source. Deposition of the sediments took place at between ca. 1299 and 1238 Ma in a back-arc basin, distal to the carbonate platform and more proximal to a magmatic arc source. The geological relationships of borosilicate-bearing gneiss are most consistent with boron having been sourced from B-rich sediments presumed to have been clay and (or) mica deposited in the protoliths. The presence of the borosilicate occurrences near the axial surfaces of syn-Ottawan folding in the host gneiss argues for their possible structural control. It is therefore proposed that breakdown of these sediments during prograde metamorphism led to mobilization of a B-rich fluid that migrated short distances to favorable structural sites in the host gneiss where the borosilicates were then precipitated.

Future studies of borosilicate occurrences in the New Jersey Highlands should include: (1) a thorough evaluation of kornerupine-absent and kornerupine-bearing biotite gneiss to search for the presence of tourmaline; (2) the acquisition of trace element (including boron) and rare earth element geochemical data of the host biotite gneiss at, and away from, sites of borosilicate mineralization; (3) petrographic and microanalysis of kornerupine and other borosilicates, where present; and (4) boron isotope analysis of kornerupine and other borosilicates in order to better constrain the source(s) of boron in biotite gneiss.

Funding: Funding for geologic mapping of the Dover and Greenwood Lake 7.5-minute quadrangles that provided the basis for part of this study was obtained through award number 99HQAG0141 to the New Jersey Geological and Water Survey under the National Cooperative Geologic Mapping Program administered by the U.S. Geological Survey.

Acknowledgments: John Dooley and Larry Müller of the New Jersey Geological and Water Survey are thanked for providing X-ray diffraction analysis of the kornerupine sample from Ringwood. I am grateful to Guest Editors for the opportunity to contribute to this Special Issue, Assistant Editor for editorial assistance, and the anonymous reviewers for their helpful comments.

Conflicts of Interest: The author declares no conflicts of interest.

\section{References}

1. Grew, E.S.; Cooper, M.A.; Hawthorne, F.C. Prismatine: Revalidation for boron-rich compositions in the kornerupine group. Miner. Mag. 1996, 60, 483-491. [CrossRef]

2. Lonker, S.W. An occurrence of grandidierite, kornerupine, and tourmaline in southeastern Ontario, Canada. Contrib. Miner. Petrol. 1988, 98, 502-516. [CrossRef]

3. Sharma, I.N.; Prakash, D. Occurrence of kornerupine-bearing granulite from Karimnagar, Andhra, Pradesh. Curr. Sci. India 2006, 91, 678-683.

4. Warren, R.G.; McColl, D.H. Occurrences of boron-bearing kornerupine in the western Harts Range and near Mount Baldwin, Arunta Block, central Australia. J. Aust. Geol. Geophys. 1983, 8, 93-96.

5. Ackermand, D.; Windley, B.F.; Razafiniparany, A.H. Kornerupine breakdown reactions in paragneisses from southern Madagascar. Miner. Mag. 1991, 55, 71-80. [CrossRef]

6. Carson, C.J.; Hand, M.; Dirks, P.H.G.M. Stable coexistence of grandidierite and kornerupine during medium pressure granulite facies metamorphism. Miner. Mag. 1995, 59, 327-339. [CrossRef]

7. Young, D.A. Kornerupine-group minerals in Grenville granulite-facies paragneiss, Reading Prong, New Jersey. Can. Miner. 1995, 33, 1255-1262.

8. Drake, A.A., Jr.; Volkert, R.A.; Monteverde, D.H.; Herman, G.C.; Houghton, H.F.; Parker, R.A.; Dalton, R.F. Bedrock Geologic Map of New Jersey; Misc. Inves. Series Map I-2540-A; U.S. Geological Survey: Reston, VA, USA, 1996. 
9. Volkert, R.A.; Aleinikoff, J.N.; Fanning, C.M. Tectonic, magmatic, and metamorphic history of the New Jersey Highlands: New insights from SHRIMP U-Pb geochronology. In From Rodinia to Pangea: The Lithotectonioc Record of the Appalachian Region; Tollo, R.P., Bartholomew, M.J., Hibbard, J.P., Karabinos, P.M., Eds.; The Geological Society of America: Boulder, CO, USA, 2010; Volume 206, pp. 307-346.

10. Volkert, R.A. Mesoproterozoic rocks of the New Jersey Highlands, north-central Appalachians: Petrogenesis and tectonic history. In Proterozoic Tectonic Evolution of the Grenville Orogen in North America; Tollo, R.P., Corriveau, L., McLelland, J., Bartholomew, M.J., Eds.; The Geological Society of America: Boulder, CO, USA, 2004; Volume 197, pp. 697-728.

11. Volkert, R.A.; Zartman, R.E.; Moore, P.B. U-Pb zircon geochronology of Mesoproterozoic postorogenic rocks and implications for post-Ottawan magmatism and metallogenesis, New Jersey Highlands and contiguous areas, USA. Precambrian Res. 2005, 139, 1-19. [CrossRef]

12. Peck, W.H.; Volkert, R.A.; Meredith, M.T.; Rader, E.L. Calcite-graphite thermometry of the Franklin Marble, New Jersey Highlands. J. Geol. 2006, 114, 485-499. [CrossRef]

13. Henry, D.J.; Guidotti, C.V.; Thomson, J.A. The Ti-saturation surface for low-to-medium pressure metapelitic biotites: Implications for geothermometry and Ti-substitution mechanisms. Am. Miner. 2005, 90, 316-328. [CrossRef]

14. Sonnenwald, E.W. Updated Pressure and Temperature Determinations from the Metapelites of the Western Hudson Highlands. Master's Thesis, Montclair State University, Montclair, NJ, USA, 2013; 115p.

15. Volkert, R.A.; Drake, A.A., Jr. Geochemistry and Stratigraphic Relations of Middle Proterozoic Rocks of the New Jersey Highlands; Professional Paper 1565-C; U.S. Geological Survey: Reston, VA, USA, 1999; 77p.

16. Volkert, R.A. Bedrock Geologic Map of the New Jersey Parts of the Greenwood Lake and Sloatsburg Quadrangles Sussex, Passaic, and Bergen Counties, New Jersey; OFM 106; New Jersey Geological and Water Survey: Ewing Township, NJ, USA, 2015.

17. Volkert, R.A. Bedrock Geologic Map of the Dover Quadrangle Morris and Sussex Counties, New Jersey; OFM 91; New Jersey Geological and Water Survey: Ewing Township, NJ, USA, 2012.

18. Volkert, R.A.; Johnson, C.A.; Tamashausky, A.V. Mesoproterozoic graphite deposits, New Jersey Highlands: Geologic and stable isotope evidence for possible algal origins. Can. J. Earth Sci. 2000, 37, 1665-1675. [CrossRef]

19. Matt, P.; Powell, W.; Volkert, R.; Gorring, M.; Johnson, A. Sedimentary exhalative magnetite deposits of the New Jersey Highlands. Can. J. Earth Sci. 2017, 54, 1008-1023. [CrossRef]

20. Dallmeyer, R.D.; Dodd, R.T. Distribution and significance of cordierite in paragneiss of the Hudson Highlands, southeastern New York. Contrib. Miner. Petrol. 1977, 33, 289-308. [CrossRef]

21. Hammerli, J.; Spandler, C.; Oliver, N.H.S. Element redistribution and mobility during upper crustal metamorphism of metasedimentary rocks: An example from the eastern Mount Lofty Ranges, South Australia. Contrib. Miner. Petrol. 2016, 171,36. [CrossRef]

22. Roser, B.P.; Nathan, S. An evaluation of element mobility during metamorphism of a turbidite sequence (Greenland Group, New Zealand). Geol. Mag. 1997, 134, 219-234. [CrossRef]

23. Rudnick, R.L.; Gao, S. Composition of the continental crust. In The Crust; Rudnick, R.L., Ed.; Elsevier: Amsterdam, The Netherlands, 2003; pp. 1-64.

24. Taylor, S.R.; McLennan, S.M. The Continental Crust: Its Composition and Evolution; Blackwell Scientific Publications: Oxford, UK, 1985; 312p.

25. Herron, M.M. Geochemical classification of terrigenous sands and shales from core or log data. J. Sediment. Petrol. 1988, 58, 820-829.

26. Nesbitt, H.W.; Young, G.M. Early Proterozoic climates and plate motions inferred from major element chemistry of lutites. Nature 1982, 299, 715-717. [CrossRef]

27. Leising, J.F.; Tyler, S.W.; Miller, W.W. Convection of saline brines in enclosed lacustrine basins: A mechanism for potassium metasomatism. Geol. Soc. Am. Bull. 1995, 107, 1157-1163. [CrossRef]

28. Bhatia, M.R.; Crook, K.A.W. Trace element characteristics of graywackes and tectonic setting discrimination of sedimentary basins. Contrib. Miner. Petrol. 1986, 92, 181-193. [CrossRef]

29. Roser, B.P.; Korsch, R.J. Provenance signatures of sandstone-mudstone suites determined using discriminant function analysis of major element data. Chem. Geol. 1988, 67, 119-139. [CrossRef]

30. Hayashi, K.-I.; Fujisawa, H.; Holland, H.D.; Ohmoto, H. Geochemistry of $\sim 1.9$ Ga sedimentary rocks from northeastern Labrador, Canada. Geochim. Cosmochim. Acta 1997, 61, 4115-4137. [CrossRef] 
31. Cox, R.; Lowe, D.R.; Cullers, R.L. The influence of sediment recycling and basement composition on evolution of mudrock chemistry in the southwestern United States. Geochim. Cosmochim. Acta 1995, 59, 2919-2940. [CrossRef]

32. Peck, W.H.; Quinan, M.P.; Selleck, B.W. Detrital zircon constraints on Grenville sedimentation at the margin of Laurentia. Precambrian Res. 2019, 331, 105342. [CrossRef]

33. Peck, W.H.; Volkert, R.A.; Mansur, A.T.; Doverspike, B.A. Stable isotope and petrologic evidence for the origin of regional marble-hosted magnetite deposits and the zinc deposits at Frankin and Sterling Hill, New Jersey Highlands, United States. Econ. Geol. 2009, 104, 1037-1054. [CrossRef]

34. Trabucho-Alexandre, J.; Hay, W.W.; de Boer, P.L. Phanerozoic environments of black shale deposition and the Wilson Cycle. Solid Earth 2012, 3, 29-42. [CrossRef]

35. Peng, Q.M.; Palmer, M.R. The Paleoproterozoic boron deposits in eastern Liaoning, China: A metamorphosed evaporite. Precambrian Res. 1995, 3-4, 185-197. [CrossRef]

36. Volkert, R.A. Geologic setting of Proterozoic iron, zinc, and graphite deposits, New Jersey Highlands. In Proterozoic Iron and Zinc Deposits of the Adirondack Mountains of New York and the New Jersey Highlands; Guidebook Ser. 35; Slack, J.F., Ed.; Society of Economic Geologists: Littleton, CO, USA, 2001; pp. 59-73.

37. Swihart, G.H.; Moore, P.B. A reconnaissance of the boron isotope composition of tourmaline. Geochim. Cosmochim. Acta 1989, 53, 911-916. [CrossRef]

38. Swihart, G.H.; Moore, P.B.; Callis, E.L. Boron isotope composition of marine and nonmarine evaporates. Geochim. Cosmochim. Acta 1986, 50, 1297-1301. [CrossRef]

39. Volkert, R.; Aleinikoff, J. 1.3 Ga continental-margin magmatic arc and back arc in the New Jersey Highlands and implications for the origin of zinc + iron deposits. Geol. Soc. Am. Abstr. Prog. 2007, 39, 37.

40. Johnson, C.A.; Rye, D.M.; Skinner, B.J. Petrology and stable isotope geochemistry of the metamorphosed zinc-iron-manganese deposit at Sterling Hill, New Jersey. Econ. Geol. 1990, 85, 1133-1161. [CrossRef]

41. Volkert, R.A.; Peck, W.H. Constraints from geochemistry and oxygen isotopes for the hydrothermal origin of orthoamphibole mafic gneiss in the New Jersey Highlands, north-central Appalachians, USA. Lithos 2017, 294-295, 184-197. [CrossRef]

42. Slack, J.F. Tourmaline associations with hydrothermal ore deposits. Boron: Mineralogy, Petrology and Geochemistry. Rev. Miner. 1996, 33, 559-643.

43. Boström, K. The origin and fate of ferromanganoan active ridge sediments. Stockholm Contrib. Geol. 1973, 27, 147-243.

44. Peter, J.M.; Goodfellow, W.D. Hydrothermal sedimentary rocks of the Heath Steele Belt, Bathurst Mining Camp, New Brunswick: Part 3. Application of mineralogy and mineral and bulk compositions to massive sulfide exploration. Econ. Geol. 2003, 11, 417-433.

45. Large, R.R.; Gemmell, J.B.; Paulick, H.; Huston, D.L. The alteration box plot: A simple approach to understanding the relationship between alteration mineralogy and lithogeochemistry associated with volcanic-hosted massive sulfide deposits. Econ. Geol. 2001, 96, 957-971. [CrossRef]

46. Plank, T.; Langmuir, C.H. The chemical composition of subducting sediment and its consequences for the crust and mantle. Chem. Geol. 1998, 145, 325-394. [CrossRef]

47. Moran, A.E.; Sisson, V.B.; Leeman, W.P. Boron depletion during progressive metamorphism: Implications for subduction processes. Earth Planet. Sci. Lett. 1992, 111, 331-349. [CrossRef]

48. Marschall, H.R.; Jiang, S.-Y. Tourmaline isotopes: No element left behind. Elements 2011, 7, $313-319$. [CrossRef]

(C) 2019 by the author. Licensee MDPI, Basel, Switzerland. This article is an open access article distributed under the terms and conditions of the Creative Commons Attribution (CC BY) license (http://creativecommons.org/licenses/by/4.0/). 